UCRL-ID-120430

\title{
THE MARSHALL ISLANDS DATA MANAGEMENT PROGRAM
}

\author{
A. Carol Stoker \\ Cynthia L. Conrado
}

September 1995

Work performed under the auspices of the U.S. Department of Energy at Lawrence Livermore National Laboratory under contract W-7405-Eng-48. 



\section{DISCLAIMER}

Portions of this document may be illegible in electronic image products. Images are produced from the best available original document. 


\section{DISCLAIMER}

This report was prepared as an account of work sponsored by an agency of the United States Government. Neither the United States Government nor any agency thereof, nor any of their employees, make any warranty, express or implied, or assumes any legal liability or responsibility for the accuracy, completeness, or usefulness of any information, apparatus, product, or process disclosed, or represents that its use would not infringe privately owned rights. Reference herein to any specific commercial product, process, or service by trade name, trademark, manufacturer, or otherwise does not necessarily constitute or imply its endorsement, recommendation, or favoring by the United States Government or any agency thereof. The views and opinions of authors expressed herein do not necessarily state or reflect those of the United States Government or any agency thereof. 


\section{Table of Contents}

List of Tables iv

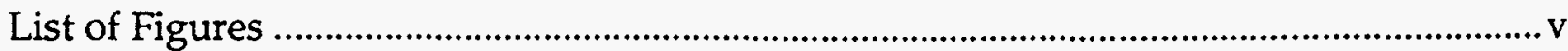

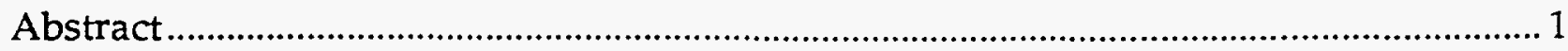

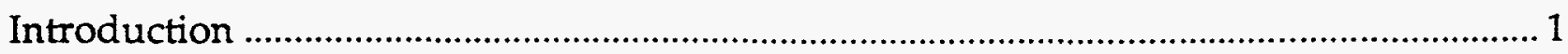

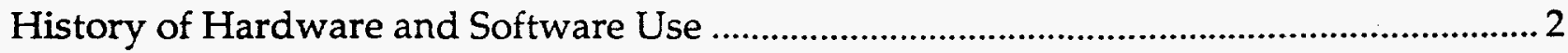

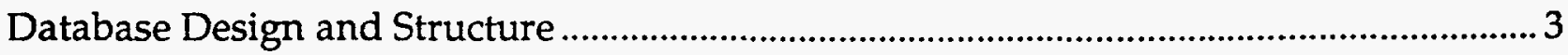

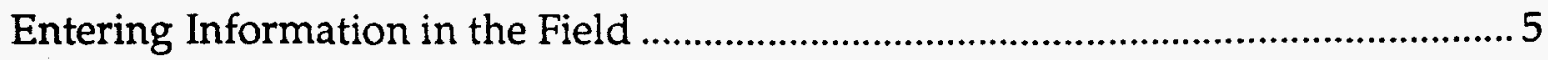

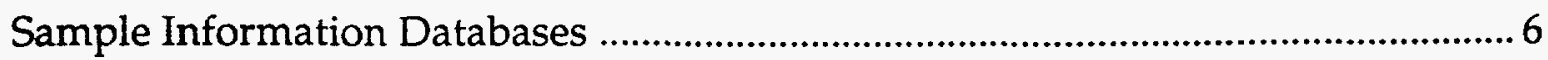

Vegetation Processing Databases................................................................... 7

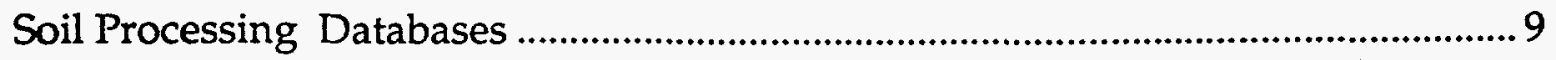

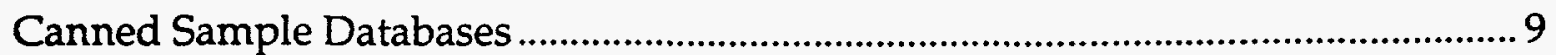

Duplicate and Quality Control Database ...................................................... 10

Radionuclide Gamma and Wet Chemistry Databases ..................................... 10

Sample and Information Management ............................................................... 11

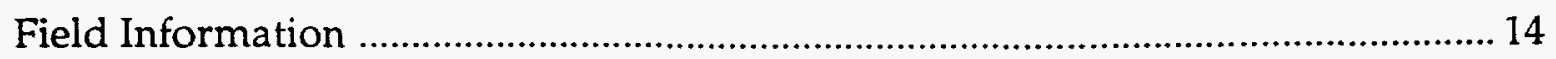

Vegetation and Animal Laboratory Information .......................................... 15

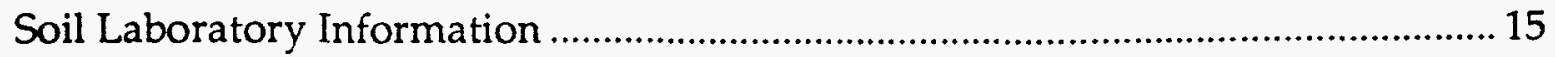

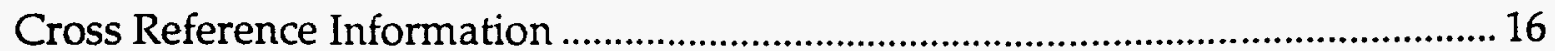

Sample Analytical Information .............................................................. 16

Sample and Radionuclide Data Evaluation ............................................................ 16

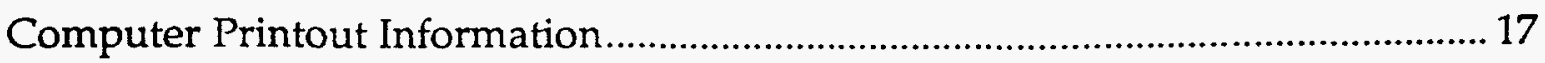

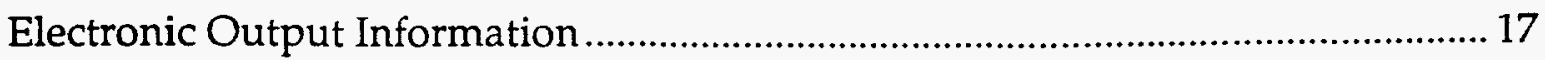

Validation of Radionuclide and Sample Information .................................... 17 


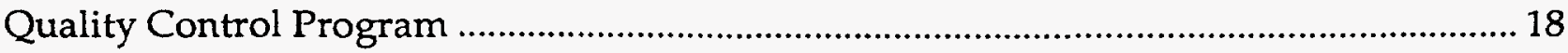

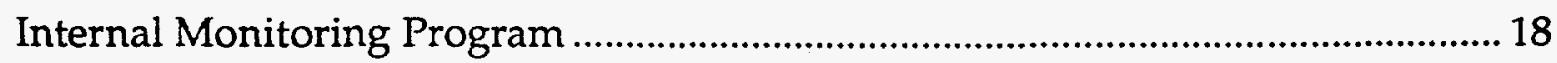

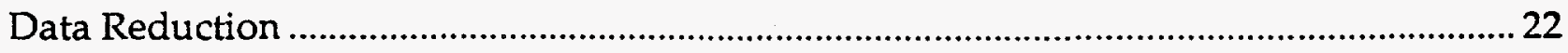

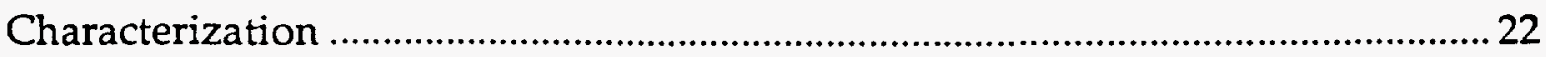

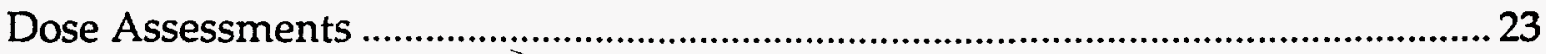

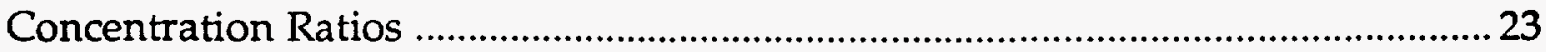

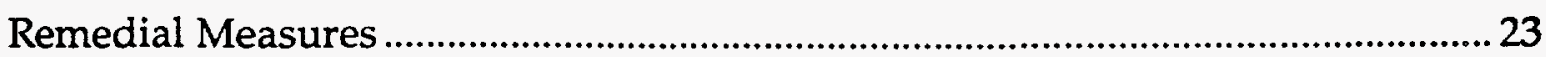

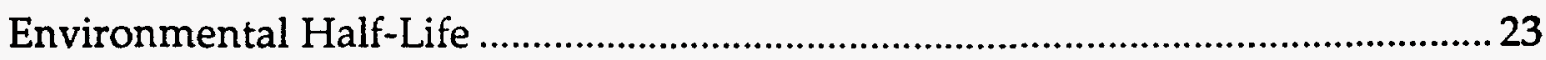

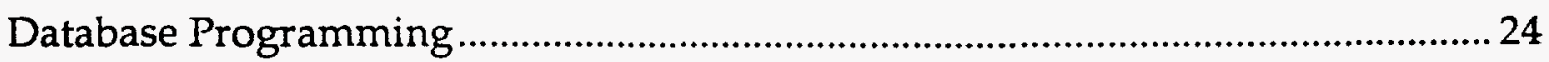

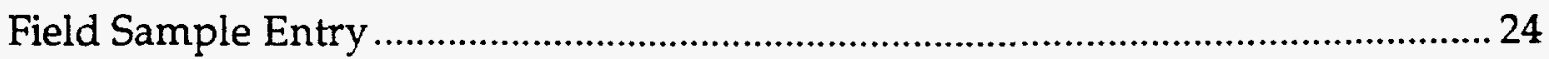

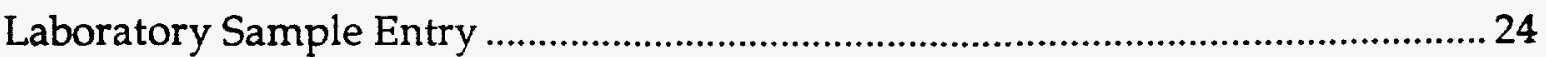

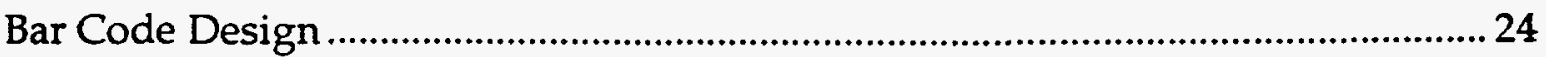

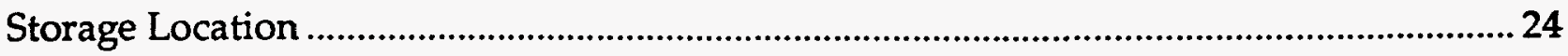

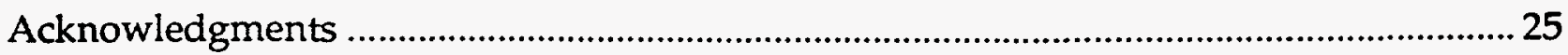

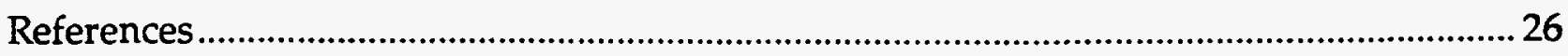

Appendix A: Commercial Software in Use in Data Management Program ................ A-28

Appendix B: Island and Atoll Designation Codes ………..............................................

Appendix C: Sample Type Designation Codes ………….................................................

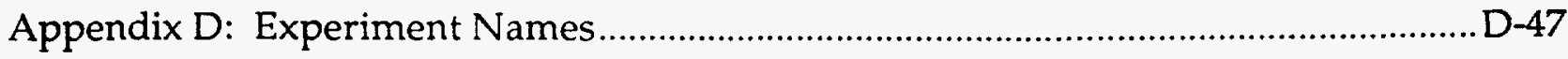

Appendix E: Number of Records Marshall Islands Database Series ..............................E-49

Appendix F: Radionuclide Isotope Designation Codes .................................................F-51

Appendix G: Data Validation Procedures for Verifying Printouts................................. G-53

Appendix H: Final Validation of Radionuclide Data Files ............................................H-58 


\section{List of Tables}

Table 1. Total Number of Samples Collected in the Marshall Islands from 1973 to 1994.

Table 2. Structure of Sample Information Database for Samples prior to $1986 \ldots \ldots \ldots \ldots . . . . . . .7$

Table 3. Structure of Sample Information Database for Samples 1987 to present.............. 7

Table 4. Structure of Vegetation Processing database for samples collected from 1987 to 1992. 8

Table 5. Structure of Vegetation Processing database for samples collected from 1993 to present.

Table 6. Structure of Soil Processing database for samples collected from 1987 to present.

Table 9. Structure of Radionuclide Gamma database for samples collected from 1973 to 1978.

Table 10. Structure of Radionuclide Gamma database for samples collected from 1979 to present.

Table 11. Structure of Radionuclide Wet Chemistry database for samples collected from 1975 to 1978.

Table 12. Structure of Radionuclide Wet Chemistry database for samples collected from 1979 to present. 13

Table 13. Finalization of databases checklist. 19

Table B-1. Islands of Bikini Atoll. B-31

Table C-1. Designation codes. C-41

Table D-1. Experiment names. D-48

Table E-1. Marshall Islands Database Series. .E-50 


\section{List of Figures}

Figure 1. Relationship between dBase database series........................................................5

Figure 2. Sample and information management from field to analysis............................ 13

Figure 3. Sample and information management from analysis to final reports. ............. 14 


\begin{abstract}
This report is a resource document of the methods and procedures used currently in the Data Management Program of the Marshall Islands Dose Assessment and Radioecology Project. Since 1973, over 60,000 environmental samples have been collected. Our program includes relational database design, programming and maintenance; sample and information management; sample tracking; quality control; and data entry, evaluation and reduction. The usefulness of scientific databases involves careful planning in order to fulfill the requirements of any large research program. Compilation of scientific results requires consolidation of information from several databases, and incorporation of new information as it is generated. The success in combining and organizing all radionuclide analysis, sample information and statistical results into a readily accessible form, is critical to our project.
\end{abstract}

\title{
Introduction
}

The Marshall Islands Dose Assessment and Radioecology Project has been in existence at Lawrence Livermore National Laboratory (LLNL) since 1973. It is a program of the Health and Ecological Assessment Division (HEA), in the Environmental Programs Directorate at LLNL. The primary purpose of this program is to assess the radiological conditions in the Marshall Islands where sixty-six nuclear tests were conducted from 1946 to 1958 as part of the United States Nuclear Weapons Program. On March 1, 1954, the BRAVO test had an explosive yield that greatly exceeded expectations, with the result that heavy fallout was experienced at Bikini Island and at atolls east of Bikini. The radiological conditions are currently being studied at the atolls of Bikini, Enewetak, Rongelap, and Utirik. In 1978 a limited survey was conducted for the atolls of Taka, Bikar, Rongerik, Ailinginae, Likiep, Ailuk, Wotho and Ujelang and the two islands of Mejit and Jemo. The primary isotopes characterized for all atolls are ${ }^{137 \mathrm{Cs}},{ }^{90 \mathrm{Sr}}$, $239+240 \mathrm{Pu}$ and $241 \mathrm{Am}$. In addition, limited characterization has been done at the uncontaminated atolls of Kwajalein and Majuro.

The radiological dose via all exposure pathways is estimated for various living patterns at the atolls. Our project is also studying remedial measures for reducing ${ }^{137} \mathrm{Cs}$ uptake in vegetation, as part of the resettlement options at Bikini Atoll.

Table 1 shows the total number of samples that have been collected during the twentytwo year history of the program. The samples include soil, edible food crops, other vegetation, fish, invertebrates, water and animals. The samples are prepared for gamma spectroscopy and/or wet chemistry and analyzed. Databases were designed for all of the information associated with the samples. 
Table 1. Total Number of Samples Collected in the Marshall Islands from 1973 to 1994.

\begin{tabular}{|c|c|c|c|c|c|c|}
\hline \multirow[b]{2}{*}{ Year Taken } & \multicolumn{5}{|c|}{ Soil and Vegetation Samples } & \multirow[b]{2}{*}{ Total } \\
\hline & $\begin{array}{l}\text { Bikini } \\
\text { Atoll }\end{array}$ & $\begin{array}{c}\text { Enewetak } \\
\text { Atoll }\end{array}$ & $\begin{array}{c}\text { Rongelap } \\
\text { Atoll }\end{array}$ & $\begin{array}{l}\text { Utirik } \\
\text { Atoll }\end{array}$ & $\begin{array}{c}\text { Other } \\
\text { Northern } \\
\text { Marshall } \\
\text { Atolls }\end{array}$ & \\
\hline 1973 & 0 & 4474 & 0 & 0 & 0 & 4474 \\
\hline 1974 & 0 & 0 & 0 & 0 & 0 & 0 \\
\hline 1975 & 941 & 0 & 0 & 0 & 0 & 941 \\
\hline 1976 & 0 & 991 & 0 & 0 & 0 & 991 \\
\hline 1977 & 998 & 728 & 0 & 0 & 0 & 1726 \\
\hline 1978 & 1556 & 124 & 728 & 463 & 2807 & $5678^{a}$ \\
\hline 1979 & 1084 & 64 & 0 & 0 & 0 & 1148 \\
\hline 1980 & 823 & 75 & 0 & 0 & 0 & 898 \\
\hline 1981 & 288 & 53 & 0 & 0 & 121 & 462 \\
\hline 1982 & 314 & 246 & 0 & 0 & 0 & 560 \\
\hline 1983 & 1008 & 180 & 0 & 0 & 166 & 1354 \\
\hline 1984 & 489 & 398 & 0 & 0 & 0 & 887 \\
\hline 1985 & 3136 & 138 & 31 & 0 & 0 & 3305 \\
\hline 1986 & 3015 & 121 & 811 & 0 & 0 & 3947 \\
\hline 1987 & 3270 & 598 & 45 & 0 & 24 & 3937 \\
\hline 1988 & 3201 & 498 & 201 & 0 & 0 & 3900 \\
\hline 1989 & 1838 & 1102 & 1315 & 0 & 0 & 4255 \\
\hline 1990 & 2629 & 576 & 524 & 0 & 137 & 3866 \\
\hline 1991 & 3527 & 556 & 635 & 0 & 0 & 4718 \\
\hline 1992 & 2859 & 365 & 819 & 0 & 0 & 4043 \\
\hline 1993 & 2449 & 1498 & 832 & 1230 & 0 & 6009 \\
\hline 1994 & 3810 & 966 & 39 & 522 & 0 & 5337 \\
\hline Others $^{b}$ & 91 & 0 & 0 & & 0 & 91 \\
\hline Total & 37326 & 13751 & 5980 & 2215 & 3255 & 62527 \\
\hline Include & 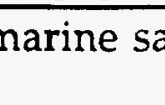 & tro & rther & hall Is & Radiolog & Survey \\
\hline
\end{tabular}

\section{History of Hardware and Software Use}

The earliest of the Marshall Island's scientific databases were run on large mainframe super computers. The original mainframes in use were the Control Data Corporation 6600 and 7600's. Later, the databases were run on the CRAY 1, CRAY XMP and CRAY YMP super computers at LLNL. The database format was different in the early 1970's. The data were in American Standard Code for Information Interchange (ASCII) text 
format. Several Formula Translation (FORTRAN) programs, written by programmers working on the project, were used to handle the data. In the late 1970's, the LLNL Computer Center offered an in house database system called FRAMIS. Although data handling was accomplished through this program, there were certain drawbacks to using the large mainframes. The computers were on a local time sharing system in another building, cumbersome to use, and on a secured system. Only personnel with a security clearance had access to the machines. Data management was very time consuming. All sample information was hand written into log books, transferred onto hand written data sheets, keypunched onto punch cards, and run through a card reader for input into the computer. The radionuclide data analysis program GAMANAL produced results for final analysis and input into FRAMIS.

With the increased affordability of personal computers in the early 1980's, the DMG recognized the need to convert from the mainframes to the personal computers. To convert to a database that could be accessed by different users simultaneously, a network operating system and database software was needed. The first personal computers were not networked. Data was shared by floppy disk exchange. The first network system was put in place in 1986, running Novell . Netware version 2.12 for a group of five personal computers. All database design and network administration were done by members of the DMG. The database software chosen to run on the network was Ashton Tate's dBase III Plus ${ }^{\circledR}$. It was chosen for ease of use and programming.

Data processing procedures are continually being updated through programming and automation. The addition of a bar code system for sample tracking is an example of an automated process developed in the last few years. Currently, there are two network servers running Novell Netware version 3.11 and 3.12. Over the years, dBase has been upgraded as new versions were released. The present version in use is 5.0. Several commercially available software packages are also used for data manipulation. See Appendix A for a list of the software currently in use.

\section{Database Design and Structure}

In the early versions of the computer databases, only the field log number, sample identification (sample ID) number, location, sample description and radionuclide data for each sample were entered. The laboratory sample wet and dry weights, and sample can information was recorded in log books. Much of the data reduction was still done by hand. Dose assessments and summaries were produced using FORTRAN programs developed by a programmer within the group. Over the last ten years, steps have been taken to improve the data acquisition and management techniques. These include use of commercially available software, and increasing the automation of data transfer where possible.

Different types of information are utilized in our data management program. We have six dBase databases for each sampling year. These inclucie the Sample Information, 
Vegetation Processing, Soil Processing, Canned Samples, Radionuclide Gamma and Radionuclide Wet Chemistry databases. All of the databases are related with one key field -- the sample ID number field. The naming convention for each database is designed to quickly identify the year in which the samples are taken. For example, information for all samples taken in 1994 will be included in the following six databases, based on the order shown above: 94SAMP, 94LAB, 94SOILWR, 94CANS, 94CONTPR and 94WETCHM. In this document, all actual database names will appear capitalized. For a general series of databases, without reference to a specific one, the name will appear with first letters capitalized only.

The Sample Information database is the main database. Working out in the field, this database is called FIELDSMP. When it is copied to the networked dBase system, the name is changed to XXSAMP ( $X X$ replaced with the sampling year code, for example 94SAMP). It contains the field log number, sample ID, sample descriptions, sampling locations and date and field notes. The difference between the current version of the Sample information database and the databases used on the mainframes for earlier sampling trips is the inclusion of all field information about the sample.

The Vegetation Processing database series contains the sample wet and dry weight information generated in the sample processing laboratories for all vegetation and animal samples. The database series names also reflect the sampling date (for example, 94LAB for all processing information for samples, other than soils, taken in 1994). The Soil Processing database, generated in the soil processing laboratory, contains similar information to the Vegetation Processing database, but for soil samples only. This database is called 94SOILWR for all soils taken in 1994. The Canned Sample database has the information generated for prepared and canned soil and vegetation samples. Information about all samples canned from the 1994 sampling trips is found in the 94CANS database. The information found in these three databases was not input into the computer prior to the implementation of the dBase system.

The Radionuclide Gamma database contains the radionuclide data generated from a Gamma Analytical Facility, either at LLNL or by an outside contractor. The gamma spectroscopy radionuclide results for all samples taken in 1994 are found in the 94CONTPR database. Similarly, the Radionuclide Wet Chemistry database contains the radionuclide data generated from a Radiochemistry Facility. The radiochemistry radionuclide results for all samples taken in 1994 are found in the 94WETCHM database.

Figure 1 shows the relationship among the six yearly databases. An arrow between boxes indicates a flow of information from one database to another.

Other databases included in the program are the DUP_QC, SAMPCODE and ISCODE databases. The DUP_QC database contains all duplicate and standard sample information. The SAMPCODE and ISCODE databases, contain sample identification number coding information used by many of the dBase programs. 


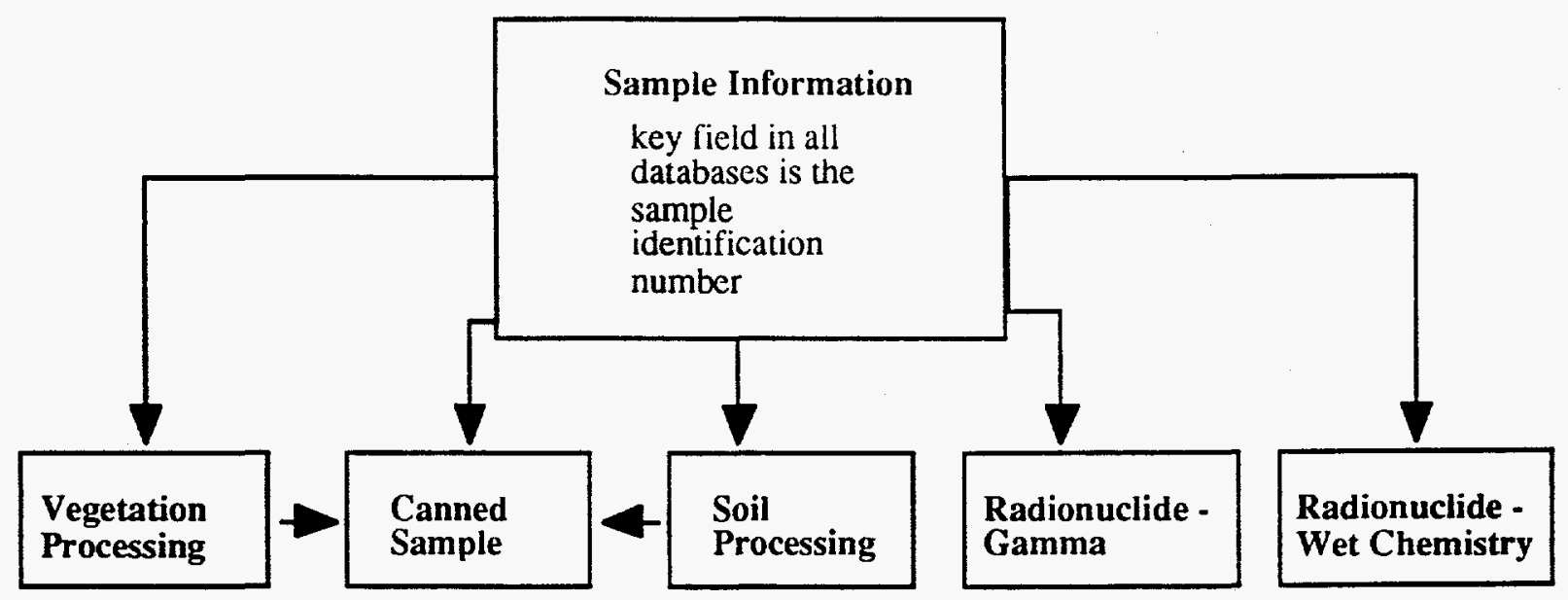

Figure 1. Relationship between dBase database series.

\section{Entering Information in the Field}

In the Marshall Islands the field crew is working in a remote location, currently averaging two sample collection trips a year. Mistakes made in the field can affect subsequent analytical data. The information about each sample is recorded in the field $\log$ book by the field crew manager. The same information is written on the sample package. Each sample is given a unique identification number, known as the field log number. The field log number is 10 characters long. The first two characters are the sampling year (for example "94" for samples taken during 1994). This is followed by an atoll designation (for example " $\mathrm{B}$ " for Bikini Atoll), and an island designation (for e.g. " $E$ " for Eneu Island) and a dash. Some islands have a two character designation. For samples taken on these islands, the dash is eliminated is the field log number. Following the dash is a 5 digit sequence number beginning at 00001 each year. The field $\log$ number given to the first sample taken in 1994 would be 94BE-00001, for a sample taken on Eneu Island, Bikini Atoll. Appendix B lists the atoll and island designations used for the field log numbers, as well as for the sample ID numbers discussed below.

The sampling date, depth of soil or description of vegetation, number of fruit if applicable, location and any other special notes that makes the sample unique are also included in the field log book. The field log number has been used to identify samples since the beginning of the program. It is short and easy to formulate in the field. The only letter designations used are for the island and atoll, and these are easily remembered, eliminating the need to look up sample codes in the field. A number known as the sample ID, which conveys more information, is generated from the information recorded in the log book, but is not recorded on the sample package itself. The use of the field log number is a convenience for the field crew members. 
The information entered into the field log book is also entered into the field sample database on a lap top computer, either back on the support ship or upon return to LLNL. Work in the field is dirty and the humidity is high. Taking the lap top computer into the field is therefore not desirable.

From the field log number, and the information in the log books, a sample ID number is created. A series of sample type and island location designations are used to include the information in the sample ID number. The early plant samples were all given the same designation, with no distinction being made between types of plant. Similarly, the soils were all coded as soil profile or soil surface samples. As the number of samples increased, a more detailed set of designations was developed. Appendix B contains the island and atoll location codes, and Appendix $\mathrm{C}$ has the sample type codes.

In the sample ID number, the first two characters are the year the sample was taken (i.e. "94" for 1994). The next two characters are the month the sample was taken (i.e. "04" for April). The next three characters are the sample type designation (example "PFA" for Copra Meat). The following three characters are the island and atoll the sample was taken on (i.e. "12B" for Eneu Island on Bikini Atoll), and finally the sequence number (example "00001"). As an example, the sample ID number given to a copra meat from Eneu Island, taken in April 1994 as the first sample of the year, would be:

\section{PFA12B00001}

The sample ID number field is the key field in every database generated. This allows relationships of information between databases to be established.

\section{Sample Information Databases}

Along with the sample and field identification numbers described above, all information collected in the field is entered into the temporary FIELDSMP database. When all records have been entered and corrected, the database is transferred to the Sample Information database for that sampling year. All records in the FIELDSMP database are deleted after the data is transferred, and before the next sample trip. Below in Tables $2 \& 3$ are the structures of the databases, and descriptions of the fields. There are currently over 60,000 records in the 1973 to 1994 Sample Information databases. The experiment name field uses the designations found in Appendix D.

Prior to 1986, when FRAMIS was used on the mainframe computers, there were no vegetation or soil laboratory information databases. The early sample information data has been transferred from FRAMIS to dBase. Because less information about the samples was originally input, there are fewer fields in the Sample Information databases for the early samples. When dBase software was introduced on the personal computer platform, the entire database system was redesigned to handle other types of information not previously included as part of the database. In addition, the logical separation of types of information was used as the criteria in designing these databases. 
Table 2. Structure of Sample Information Database for Samples prior to 1986.

Field Name Type of Field $\quad$ Description of Field Name

\begin{tabular}{lll} 
GAMMA_NUM & Character & Sample ID number \\
FIELD_LOG & Character & Field log number \\
ASSOC_NUM & Character & Association number that correlates data to location \\
XREF_NOTES & Character & Description of sample taken in field \\
LOC_CODE & Character & Location where sample was taken \\
SAMP_WT & Numeric & Weight in grams of sample canned into a container \\
NORM_WT & Numeric & Dry weight/wet weight ratio representing \% water \\
LEFT_SAMP & Numeric & Weight in grams of leftover sample \\
DUP_SAM_NO & Character & Duplicate sample identification number, if made \\
DUPSSAM WT & Numeric & Weight in grams of duplicate sample \\
\hline
\end{tabular}

Table 3. Structure of Sample Information Database for Samples 1987 to present.

Field Name Type of Field Description of Field Name

\begin{tabular}{lll} 
GAMMA_NUM & Character & Sample ID number \\
FIELD_LOG & Character & Field log number \\
SAMP_DATE & Date & Sampling date in field \\
MLS_OJ_FLD & Numeric & Milliliters of juice measure in field \\
DEPTH_SOIL & Character & Depth of soil increment \\
NUM_FRUIT & Character & Number of individual fruits in sample \\
ASSOC_NUM & Character & Association number that correlates data to location \\
EXPER_NAME & Character & Experiment name \\
LOC_CODE & Character & Location where sample was taken \\
LOC_NOTES & Character & Sampling notes taken in field \\
XREF_NOTES & Character & Description of sample \\
QUESTION & Logical & Special Notes \\
\hline
\end{tabular}

\section{Vegetation Processing Databases}

The Vegetation Processing database was designed for all information generated in the vegetation processing laboratories. Below, in Tables 4 and 5 is the structure and descriptions of these databases. For the years 1987 through 1995, there are over 62,000 records. (Appendix E). Food crops, indicator species and animals are dissected and freeze-dried. Liquids are processed differently. Each record represents one carton of dissected sample or one juice container. The container tare weight is not included in any of the measurements. Before 1987, this information was recorded in the laboratory sample log books, and was not input into a database. 
Table 4. Structure of Vegetation Processing database for samples collected from 1987 to 1992.

Field Name Type of Field

GAMMA_NUM Character

CARTON_NUM Character

ORIG_WT Numeric

DRY_WT Numeric
Sample ID number

Number on individual sample carton

Weight : jrams of wet sample in carton

Weight grams of sample in carton after freeze drying

CUT_DATE Date

MLS_OJ_LAB Numeric

C TUBE WT Numeric
Date sample was thawed, cut and put in cartons

Milliliters of juice measure in laboratory

Weight in grams of juices prepared with AMP*

* Method of processing juices changed in 1992. See Stuart 1995 for description of the methods used.

Table 5. Structure of Vegetation Processing database for samples collected from 1993 to present

Field Name Type of Field

Description of Field Name

\begin{tabular}{|c|c|c|}
\hline $\begin{array}{l}\text { GAMMA_NUM } \\
\text { CARTON_NUM }\end{array}$ & $\begin{array}{l}\text { Character } \\
\text { Character }\end{array}$ & $\begin{array}{l}\text { Sample ID number } \\
\text { Number on individual sample carton }\end{array}$ \\
\hline ORIG_WT & Numeric & Weight in grams of wet sample in carton \\
\hline DRY_WT & Numeric & $\begin{array}{l}\text { Weight in grams of sample in carton after freeze } \\
\text { drying }\end{array}$ \\
\hline CUT_DATE & Date & Date sample was thawed, cut and put in cartons \\
\hline TTUBEE_HT & Numeric & Height of AMP centrifuged juice sample (in $\mathrm{cm}$.) \\
\hline TRACER & Character & $\begin{array}{l}\text { Designation for Cs } 134 \text { standard added as tracer in } \\
\text { juices }\end{array}$ \\
\hline TRACER WT & Numeric & Weight of tracer added (in grams) \\
\hline
\end{tabular}

The change in database structure was a result of changes in laboratory procedures for juice processing, Prior to the December 1992 field trip, the juices were measured by volume, evaporated in a drying oven and then canned. A new procedure was introduced which relied on the extraction of cesium onto the cation exchanger, ammonium molybdophosphate (AMP). From the December 1992 field trip, some of the juices were processed using both methods to evaluate the effect of the change in procedure on the radionuclide analytical results. These samples are identified in the "notes" field in the Canned Sample database described later. Beginning in 1993, the addition of a ${ }^{134} \mathrm{Cs}$ tracer was included to assess the recovery rate of the ${ }^{137} \mathrm{Cs}$. The current procedure is described in Stuart 1995. The information in these databases is entered by laboratory personnel as the samples are being processed. 


\section{Soil Processing Databases}

The Soil Processing databases contain the wet and dry weights, as well as the soil fraction weights for all soils processed in our soil facility as discussed in Stuart 1995. Since 1987, over 6800 records have been input into the Soil Processing databases (Appendix E). Prior to that date, the information is found in the handwritten laboratory sample log books. The structure and design is in Table 6.

\section{Canned Sample Databases}

The series of Canned Sample databases contains the completed sample information, including canned sample weight, the wet to dry ratio, the container type and leftover sample weights for all completed samples. The canning date, sample weight, and container type information is entered by the laboratory personnel. The wet to dry ratio and leftover sample weights are calculated in dBase programs. The wet to dry ratio is used to convert the radionuclide analytical results, which are reported on a dry weight basis, into wet weight results. The leftover sample weight is useful for determining if enough sample remains to prepare an additional canned sample when necessary. Table 7 contains the structure and design of the databases. For samples collected since 1987 , over 32,000 records have been input, each representing a canned sample (Appendix E).

Table 6. Structure of Soil Processing database for samples collected from 1987 to present.

\begin{tabular}{lcl}
\hline \multicolumn{1}{c}{ Field Name } & Type of Field & \multicolumn{1}{c}{ Description of Field Name } \\
\hline GAMMA_NUM & Character & Sample ID number \\
FIELD_LOG & Character & Field log number \\
ORIGWETWT & Numeric & Weight of bulk sample before drying (in grams) \\
ORIGDRYWT & Numeric & Weight of bulk sample after drying (in grams) \\
LGTARE & Numeric & Tare weight of large soil can (in grams) \\
ORIGFINE & Numeric & Weight of fine sample fraction (in grams) \\
LEFTCOARSE & Numeric & Weight of coarse sample fraction (in grams) \\
\hline
\end{tabular}

Table 7. Structure of Canned Sample database for samples collected from 1987 to present.

\begin{tabular}{|c|c|c|}
\hline Field Name & Type of Field & Description of Field Name \\
\hline$\overline{\text { GAMMA_NUM }}$ & Character & Sample ID number \\
\hline FIELD_LÖG & Character & Field log number \\
\hline NORM_WT & Numeric & Dry wt/wet wt ratio representing $\%$ water in sample \\
\hline SAMP_WT & Numeric & $\begin{array}{l}\text { Weight in grams of sample canned in container for } \\
\text { analysis }\end{array}$ \\
\hline DATE_CAND & Date & Date sample is canned into a container \\
\hline CONT_TYPE & Character & Type of container sample is canned in \\
\hline LEFT_SAMP & Numeric & Weight in grams of leftover sample after canned \\
\hline NOTES & Character & Notes related to sample processing \\
\hline
\end{tabular}




\section{Duplicate and Quality Control Database}

The DUP_QC database is used for our Quality Control $(\mathrm{QC})$ program. It is used and maintained by the DMG to keep track of all duplicate and standard samples made. This information is not available to the personnel working in the HEA Low Level Gamma Analytical Facility (LLGAF).

The duplicates are prepared by the vegetation and soil processing laboratory personnel as part of the sample process QC. The sample ID number for the original sample from which the duplicate was made, the duplicate can sample number, and the duplicate can weight are entered into the database. The DUP_QC database contains sample information for all duplicates made since 1987. Duplicate sample information for the years 1978 through 1986 is incorporated into the Sample Information databases.

The standard samples are prepared from a known certified standard. Data for all standards prepared and analyzed prior to 1993, is organized separately in computer spreadsheets, and is not included in the DUP_QC database.

The number of records for duplicate and standards analyzed since 1987 is presently over 2600. The structure and design is described in Table 8.

\section{Radionuclide Gamma and Wet Chemistry Databases}

The radionuclide analytical data is found in two different databases depending on the type of analysis done. For samples analyzed by gamma spectroscopy, the data is

Table 8. Structure of DUP_QC database for samples collected from 1987 to present.

Field Name Type of Field Description of Field Name

\begin{tabular}{lll} 
GAMMA_NUM & Character & Sample ID number of original sample \\
FIELD_LOG & Character & Field log number \\
DUP_SAM_NO & Character & Duplicate or standard sample identification number \\
DUP_SAM_WT & Numeric & Weight in grams of duplicate sample or standard \\
SAMP_DESC & Character & Description of duplicate or standard \\
\hline
\end{tabular}

included in the Radionuclide Gamma databases. Radionuclide analytical data for samples analyzed by wet chemistry is found in the Radionuclide Wet Chemistry 
databases. Below, in Tables 9, 10, 11 and 12, are the structures and descriptions of our radionuclides databases. There are over 470,000 records in the Radionuclide Gamma databases and over 17,000 records in the Radionuclide Wet Chemistry databases (Appendix E).

Prior to 1978 all of the analytical results were reported on a dry weight basis. In 1979, the analytical reporting procedures were changed and all vegetation and plant sample results were reported on a wet weight basis. The soil analyses are reported on a dry weight basis. All results are reported as decays per minute (dpm). The additional fields for values in pico-Curies ( $\mathrm{pCi}$ ) and Becquerels $(\mathrm{Bq})$ are calculated by a simple dBase program. They exist only for the convenience of the DMG in compiling summaries, when results may need to be reported using different units.

The addition of the fields for detector, spectrum identification number and calibration can are for use by the Quality Control group.

\section{Sample and Information Management}

The organization of the variety of information associated with each sample, produced at different times during sample preparation and analysis, is important. From field collection to final storage, the DMG must be able to track all samples and their associated sample information and radionuclide data. It is the responsibility of this group to be able to produce information bases, inventories, results, and reports for any sample or group of samples. Figures 2 and 3 show the steps used in managing the flow of information produced at different stages of the MI project.

Table 9. Structure of Radionuclide Gamma database for samples collected from 1973 to 1978.

Field Name Type of Field

RADIONUCLIDE

VALUE_DPM

VALUE_PCI

VALUE_BEQ

ERROR

GAMMA_NUM

DUP

LAB

CONT TYPE

Character
Character Radionuclide isotope designation (1)

Float Value in dpm/gram dry weight

Float Value in pCi/gram dry weight

Float Value in becquerels/gram dry weight

Numeric Percent error of value

Character Sample ID number

Character Designation for samples counted more than once

Character Analytical laboratory performing analysis

Type of sample container

(1) Appendix F 
Table 10. Structure of Radionuclide Gamma database for samples collected from 1979 to present.

\begin{tabular}{|c|c|c|}
\hline Field Name & Type of Field & Description of Field Name \\
\hline RADIONUCLIDE & Character & Radionuclide isotope designation (1) \\
\hline \multirow[t]{2}{*}{ VALUE_DPM } & Float & Value in dpm/gram dry weight for soils \\
\hline & & $\begin{array}{l}\text { Value in dpm/gram wet weight for vegetation and } \\
\text { animals }\end{array}$ \\
\hline \multirow[t]{2}{*}{ VALUE_PCI } & Float & Value in $\mathrm{pCi}$ /gram dry weight for soils \\
\hline & & $\begin{array}{l}\text { Value in } \mathrm{pCi} \text { /gram wet weight for vegetation and } \\
\text { animals }\end{array}$ \\
\hline VALUE_BEQ & Float & $\begin{array}{l}\text { Value in becquerels/gram dry weight for soils } \\
\text { Value in Bq/gram wet weight for vegetation \& } \\
\text { animals }\end{array}$ \\
\hline ERROR & Numeric & Percent error of value \\
\hline GAMMA_NUM & Character & Sample ID number \\
\hline DUP -1 & Character & Designation for samples counted more than once \\
\hline LAB & Character & Analytical laboratory performing analysis \\
\hline CONT_TYPE & Character & Type of sample container \\
\hline DETECTTOR & Character & $\begin{array}{l}\text { Detector sample was counted on (LLNL Gamma } \\
\text { Facility) }\end{array}$ \\
\hline SPEC_ID & Character & $\begin{array}{l}\text { Spectrum identification number (LLNL Gamma } \\
\text { Facility) }\end{array}$ \\
\hline CALIB CAN & Character & Geometry \& material for sample calibration \\
\hline
\end{tabular}

(1) Appendix F

Table 11. Structure of Radionuclide Wet Chemistry database for samples collected from 1975 to 1978.

Field Name Type of Field

RADIONUCLIDE Character Radionuclide isotope designation(1)

VALUE_DPM Float Value in dpm/gram dry weight

VALUE_PCI

Float Value in $\mathrm{pCi}$ /gram dry weight

VALUE_BEQ

Float Value in becquerels/gram dry weight

ERROR

Numeric

GAMMA_NUM

Character

Percent error of value

DUP

Character

Sample ID number

Designation for samples counted more than once

LAB Character Analytical laboratory who did the analyses

(1) Appendix F 
Table 12. Structure of Radionuclide Wet Chemistry database for samples collected from 1979 to present.

\begin{tabular}{lcl}
\hline Field Name & Type of Field & Description of Field Name \\
\hline $\begin{array}{l}\text { RADIONUCLIDE } \\
\text { VALUE_DPM }\end{array}$ & $\begin{array}{c}\text { Character } \\
\text { Float }\end{array}$ & $\begin{array}{l}\text { Radionuclide isotope designation (1) } \\
\text { Value in dpm/gram dry weight for soils } \\
\text { Value in dpm/gram wet weight for vegetation and } \\
\text { animals }\end{array}$ \\
VALUE_PCI & Float & $\begin{array}{l}\text { Value in } \mathrm{pCi} / \text { gram dry weight for soils } \\
\text { Value in pCi/gram wet weight for vegetation and } \\
\text { animals }\end{array}$ \\
VALUE_BEQ & Float & $\begin{array}{l}\text { Value in becquerels/gram dry weight for soils } \\
\text { Value in Bq/gram wet weight for vegetation \& } \\
\text { animals }\end{array}$ \\
ERROR & Numeric & $\begin{array}{l}\text { Percent error of value } \\
\text { GAMMA_NUM }\end{array}$ \\
DUP & $\begin{array}{l}\text { Character } \\
\text { Chample ID number }\end{array}$ \\
LAB & Character & $\begin{array}{l}\text { Designation for sample counted more than once } \\
\text { Analytical laboratory performing analysis }\end{array}$ \\
\hline
\end{tabular}

(1) Appendix F

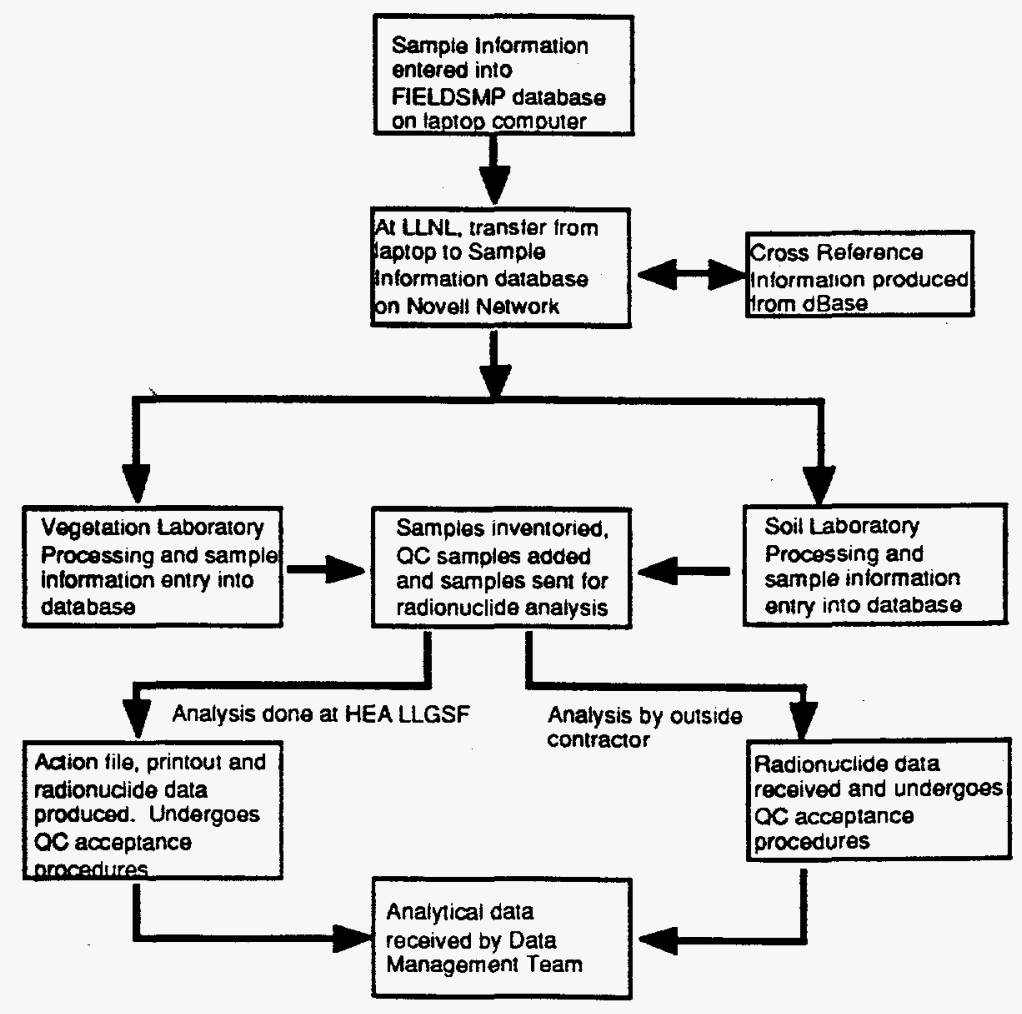

Figure 2. Sample and information management from field to analysis. 


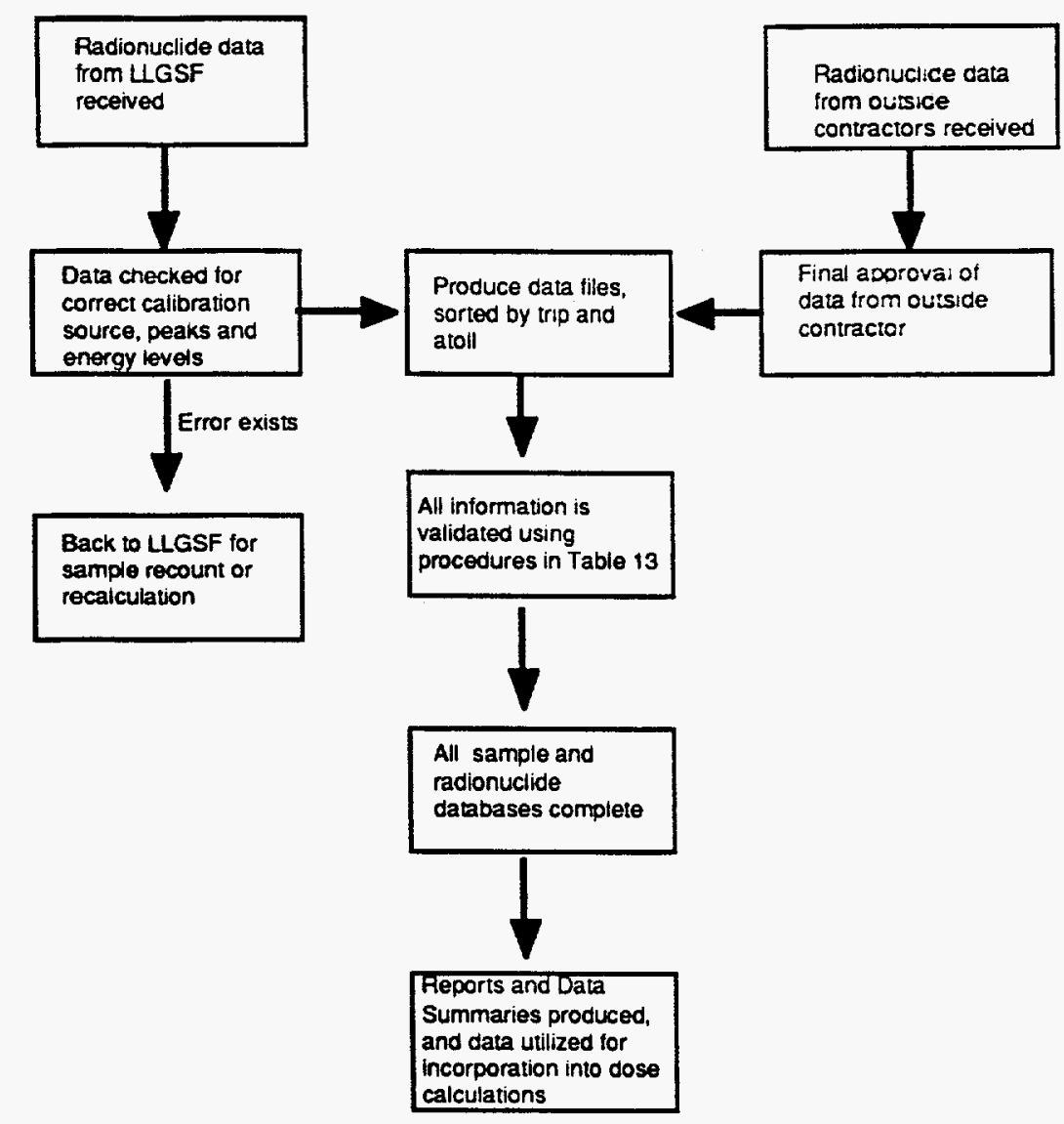

Figure 3. Sample and information management from analysis to final reports.

After a sample is collected in the field, it is prepared for analysis in the laboratories. A series of dBase programs have been written by the DMG for field and laboratory data entry. These programs provide entry screens, with error checking built in. They also allow access to databases to be controlled. The data entry screens have the advantage of controlling the types of data allowed into each field through the use of templates. Fields can also automatically be filled in, which helps improve speed and accuracy of data entry. The field and laboratory personnel are responsible for the data entry. Before analysis, the DMG ensures that all of the sample information has been entered into the Sample Information, Vegetation Processing, Soil Processing, Canned Sample, and DUP_QC databases, and makes additions or corrections as needed.

\section{Field Information}

The data management effort starts in the field when the samples are collected. Soil, vegetation and animal samples are the majority of the specimens collected as discussed in Stuart 1995. The following information about each sample is entered by the field team manager through a dBase entry screen programmed for field sample entry: sample ID number, field log number, depth of soil increment or number of individual fruit, 
experiment name, and notes describing sample and location. Upon returning to LLNL, the field team manager verifies all field sample information. This database is transferred electronically to the networked computer system and appended to the Sample Information database by DMG personnel.

\section{Vegetation and Animal Laboratory Information}

The samples are frozen in the field and shipped to LLNL where they are processed in our laboratories as discussed in Stuart 1995. From the information in the Sample Information database, a sample log book is printed for the vegetation laboratory personnel. Both plant and animal samples are dissected, put into bar code labeled cartons and weighed. The following information is entered into a Vegetation Processing database through a dBase entry screen programmed for laboratory sample entry: sample ID number, carton number, wet weight and cut date. After freeze drying, the dry weight is entered through the same entry screen. When all cartons for a sample are dried, the percent water content for the sample is calculated using a dBase program.

The sample is ground and canned as discussed in Stuart 1995 for gamma spectroscopy analysis and/or wet chemistry analysis. The following information is entered through a dBase entry screen into the Canned Sample database: sample ID number, sample weight, container type and date ground. Leftover sample weight is calculated in a dBase program. The following is also entered into the DUP_QC database using a different data entry screen: original sample ID number, field log number, duplicate sample identification number, duplicate sample weight and sample description. A bar code label is applied to each sample can with the sample ID number and weight. Samples are boxed for analysis as discussed under the QC Program.

\section{Soil Laboratory Information}

The soil samples are frozen in the field and shipped separately from the vegetation and animal samples. They are processed in a separate soil laboratory, to ensure there is no cross contamination between the vegetation and soil. From the information in the Sample Information databases, a soil sample log book is printed for the soil laboratory personnel. The soils are made ready for drying in the ovens and the following information is entered into the Soil Processing database through a dBase entry screen: field log number, large gallon can tare weight and large can wet weight. The soils are dried, ball milled, and sieved into two fractions and the following information is entered through the same entry screen: large can dry weight, fine sample weight and coarse sample weight.

The soil samples are then canned for gamma spectroscopy analysis and/or wet chemistry analysis. Sample ID number, sample weight and container type are entered through a dBase entry screen into the Canned Sample database. Original sample ID number, duplicate sample ID number, duplicate sample weight and sample description are entered through the a different entry screen into the DUP_QC database. A bar code 
label is applied with the sample ID and weight for each sample can. Samples are boxed for analysis as discussed under the QC Program.

\section{Cross Reference Information}

A trip report and cross reference file (CRF) is generated from the information entered in the field. The data managers and field team manager use the trip report and CRF's for planning, setting priorities, finding and discussing discrepancies, correcting and making additions to the Sample Information database.

The trip report is produced from the FIELDSMP database. It is summarized in three different ways: by experiment, sample type, and location. The field team manager uses this report to find and correct discrepancies from the FIELDSMP database. The corrected information from FIELDSMP is imported into the Sample Information database. The final trip report is issued to the principal investigator and the data managers. Sample processing priorities can then be finalized.

The CRF's consist of field log number, sample ID number, association number, sample description, experiment name and location code. There is a CRF for each trip and atoll. The DMG uses these for finding and correcting discrepancies the field team manager may have missed. Association numbers are added to link vegetation and soil samples collected at the same location. Location and experiment names are verified. Additional cross reference information for use by the data managers is added. All corrections and additions to these files are updated into the Sample Information database.

\section{Sample Analytical Information}

Samples sent to the HEA LLGAF are logged in for gamma spectroscopy analysis by the analyst. The information for each sample includes sample ID number, sample type, sample location, sample weight, units for result reporting, zero time, start date, detector and spectrum identification number. From this information an action file is created. The sample ID's in the action file are compared with sample ID's in the cross reference file. This allows the LLGAF personnel to track the samples, and to determine when analysis of all samples from a trip and atoll is complete. The printout and electronic file generated from the gamma spectroscopy analysis program includes radionuclide data and associated sample analysis information.

\section{Sample and Radionuclide Data Evaluation}

Radionuclide isotope data is generated from gamma spectroscopy or radiochemistry analysis. The majority of our samples are first analyzed at the HEA Low Level Gamma Analytical Facility (LLGAF) at LLNL. Occasionally, samples are analyzed by outside contracting laboratories. After gamma spectroscopy analysis, some samples may be selected for radiochemistry analysis. Currently, samples are being analyzed for wet 
chemistry at the HEA Radiochemistry Facility at LLNL. In the past, samples were sent to outside contractors for wet chemistry. Hard copy and electronic forms of the sample and radionuclide data generated from all facilities are checked and verified by the DMG.

\section{Computer Printout Information}

For every sample analyzed at the HEA LLGAF, a printout of radionuclide results and sample information is generated by the gamma analysis program GENIE. Printouts are checked to ensure that the sample ID number corresponds with the year and the first day of the month a trip was started. Radionuclide data must be decay corrected to this date. Sample geometry is checked against the calibration to verify that the correct configuration was used for the analysis. Peaks and energy levels of isotopes are checked for double peaks or peaks that have shifted. If errors exist, the sample must be recalculated or recounted. Recalculations, using the same gamma spectrum, are made when an input value is incorrect or when there has been a shift in the peak spectrum. The analysis program is run again using the correct input values. In the case of a peak shift, the spectrum is adjusted and the nuclide identification is redone. Recounts, occurring when there is a double peak, require that the sample be physically placed in the detector, and analyzed again, resulting in a new spectrum. A more detailed set of procedures can be found in Appendix G. All printouts are filed by year, month and sequence number for final radionuclide data validation using the procedures in Appendix $\mathrm{H}$.

Printouts for samples analyzed by an outside contractor contain radionuclide data and sample information only.

\section{Electronic Output Information}

For each sample analyzed, an ASCII text file is generated by the HEA LLGAF. It contains the following information: isotope, numeric value, percent error, units, container type, sample ID number, spectrum ID, detector number, calibration type, analysis date and lab designation. These files are electronically transferred to the Novell network from the VAX running the GENIE radionuclide analysis program. Outside contractors for gamma spectroscopy and radiochemistry provide radionuclide data on a floppy disk. A series of ASCII radionuclide data text files for each trip and atoll is created, using data from all analytical facilities. Radionuclide and sample data is validated using the procedures in Appendix $G$.

\section{Validation of Radionuclide and Sample Information}

Samples from a particular sampling trip are usually processed and analyzed together as a group. Sample information should be complete and correct in the Sample Information, Vegetation Processing, Soil Processing, and Canned Sample databases before analysis. Once the radionuclide data is released from the QC manager and verified against the 
printouts using the procedures in Appendix $\mathrm{H}$, this data can be imported into the Radionuclide Gamma database.

Verification and validation of all databases is needed because errors do occur in data entry. The DMG runs a series of dBase and FORTRAN programs during and after the samples are analyzed to ensure that all radionuclide and sample information is complete. In Table 13 is the list of steps taken for each trip and atoll to accomplish this task. Each step is initialed and dated when complete. The data managers are confident that all sample and radionuclide data is complete and correct at this point. Any discrepancies are documented after completion of this checklist. The radionuclide data is imported into a Radionuclide Gamma database. The checklist is filed for the final documentation of completion.

Wet Chemistry radionuclide analysis is performed at a later date and on a small percentage of the samples collected. Once analyzed and released from the $\mathrm{QC}$ manager a FORTRAN program is run to identify any discrepancies in the sample ID and format. This data is then imported into a Radionuclide Wet Chemistry database.

\section{Quality Control Program}

The Marshall Islands Quality Control (QC) Program includes evaluation of analytical work performed by outside contractors and our own analytical facility in the HEA Division. The Internal Monitoring Program (IMP) of the HEA Low Level Gamma Analytical Facility (LLGAF) at LLNL for gamma spectroscopy radionuclide analysis is discussed briefly below. The External Monitoring Program (EMP) implemented for outside contractors performing both gamma and wet chemistry radionuclide analysis is discussed in Kehl et al 1995. Our HEA Radiochemistry Facility at LLNL is considered an external outside contractor for the purpose of QC discussion.

\section{Internal Monitoring Program}

The internal monitoring program begins when the samples are entered into the Sample Information database. The number of duplicates and standards needed can be determined. Duplicates are made for approximately $10 \%$ of the samples submitted for analysis for each experiment or island sampled, to ascertain the precision (reproducibility) of analyses and the homogeneity of the samples. Reference standards, $5 \%$ of the total number of samples submitted for analysis, are used to establish the accuracy of the measurements. A sample ID number, similar to the sample ID number of the samples being sent for gamma spectroscopy is given to the sample duplicate and 
Table 13. Finalization of databases checklist.

FINALIZATION OF DATABASES

CHECKLIST

Trip

Atoll Name

Atoll

Designation
Samples Collected

Vegetation

Samples

Soil Samples

Others

Dups Needed

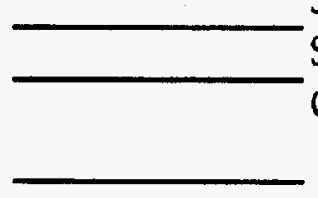

Total

Date

Completed

Initials

Check List

Description

Sample Information dBase

Database

1 Input

Complete

2 Run Findum

3 Corrections

4 Final Check

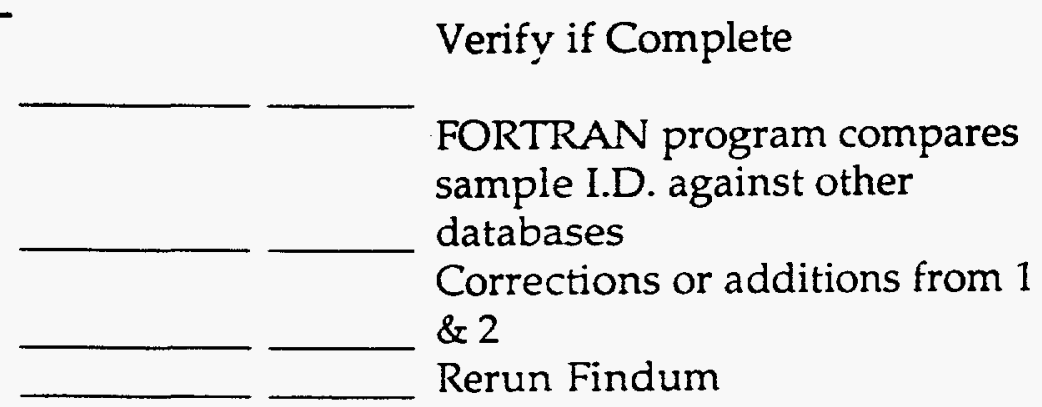

Cross Reference File

1 Generated

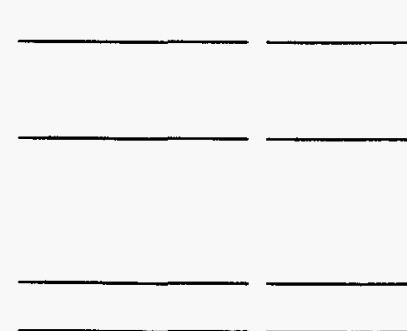

Generate from Sample

Database

2 Loc_Code

Verify Location

3 Assoc_num

Create to associate soil \& veg. location

4 Run Findum

Program to compare sample I.D.

5 Corrections

against data files \& action files

6 Final Check

Corrections or additions from $2,3 \& 4$ 
Table 13. Finalization of databases checklist continued.

Rerun Findum

Canned Sample dBase Database

1 Input
Complete
2 Run Update \&

Compare

3 Missing in

Notes

4 Run Findum

5 Corrections

6 Final Check

Vegetation Processing Database

1 Input

Complete

2 Run Findum

3 Run Labcorr

4 Corrections

5 Final Check

Soil Processing Database

1 Input

Complete

2 Run Findum
Verify if complete

dBase program compares dry/wet wt.

ratios to sample type \& changes

Sample I.D. to databases if needed

Information about missing samples

Program to compare sample

I.D. against other databases

Checklist of changes made to databases is produced

Rerun Findum \& UpdateCompare

Verify if complete

Program compares sample I.D. against other databases

dBase program to check for discrepancies in wet and dry weights

Corrections or additions from 1 , $2 \& 3$

Rerun Findum \& Labcorrect

Verify if complete

Program compares sample I.D. against other databases 
Table 13. Finalization of databases checklist continued.

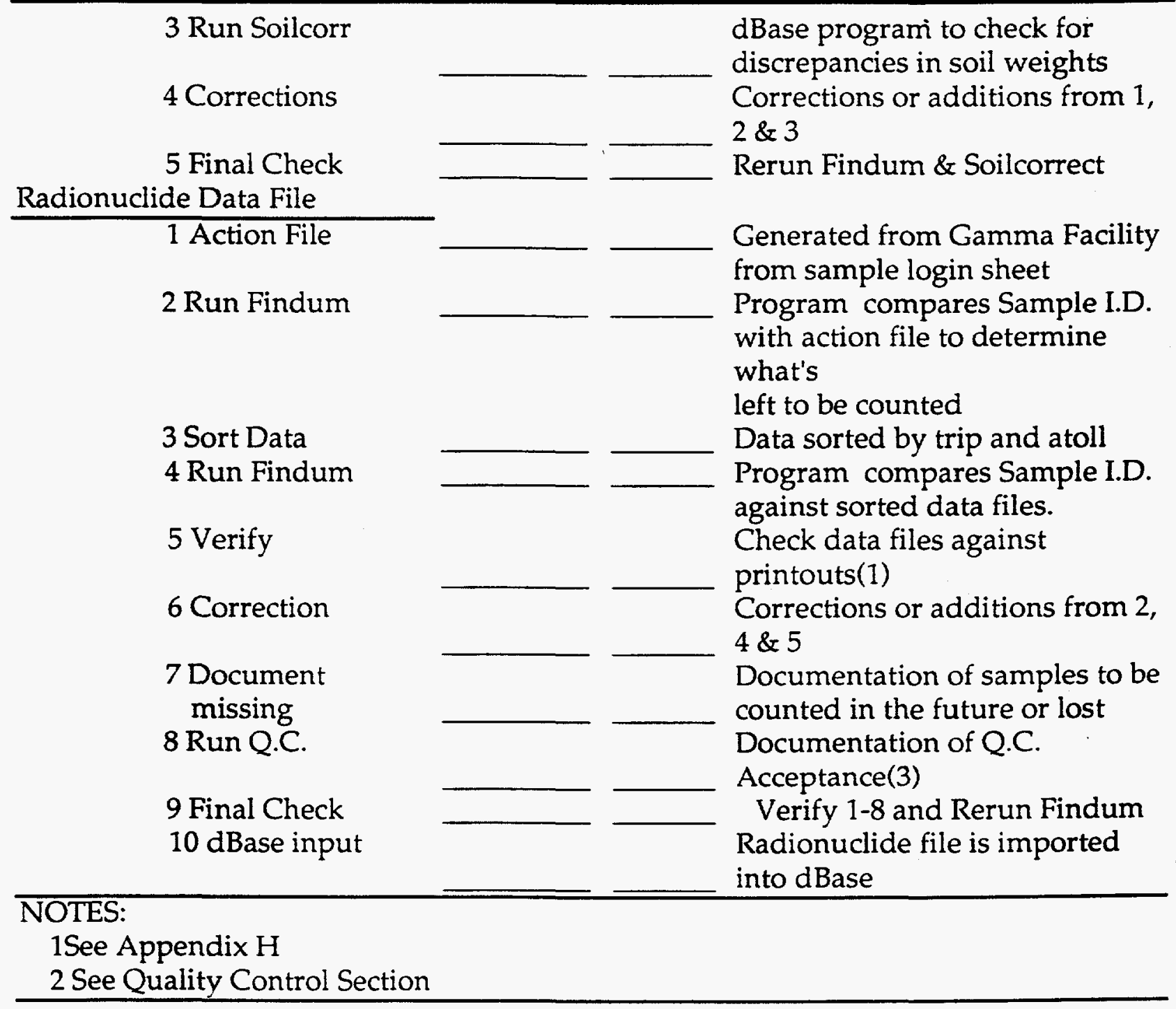

reference standard containers, to ensure the true identification is unknown to the analyst. The internal and external monitoring programs use the same set of standards. The preparation of standards and duplicates and certification of standards are discussed in Kehl 1995.

Before the samples are sent to the HEA LLGAF for analysis, the bar coded sample ID number on each sample container is scanned into the computer. The list of samples, duplicates and standards, used for QC documentation, is called an IMP form. An IMP form is made for each box of samples sent for gamma spectroscopy analysis. The standard IMP form, prepared for each box of vegetation and soil samples in steel cans or prindle vials, contains 72 sample cans. This box contains 6 duplicate pairs and 3 reference standards.

Aqueous samples (water and coconut fluid) are processed in centrifuge sample tubes. In addition to the ten percent duplicates and five percent standards, an additional five 
percent reagent blanks are included for each set of sample tubes in an Aqueous IMP form. Preparation of duplicates, standards, and blanks are discussed in Stuart 1995. An IMP form produced for each box of aqueous samples contains a total of 100 sample tubes, with 8 duplicate pairs, 4 standards and 4 blanks.

After analysis, and before any radionuclide data can be released to the principal investigator or imported into the radionuclide databases, each individual IMP form must pass our QC precision requirements. To be in compliance, $80 \%$ of the duplicate pairs and $100 \%$ of the standards are required to pass the $\mathrm{QC}$ criteria. This evaluation criteria is discussed in Kehl 1995. Past and current internal monitoring QC results will be presented in another report (Conrado 1995).

When the samples are returned from the gamma analytical facility they are inventoried. A permanent label and list is applied to the storage box. The standards are pulled out for reuse, due to the limited number of standards available.

\section{Data Reduction}

All sample and radionuclide data from a field trip, is considered complete after validation and importation into the $\mathrm{dBase}$ databases. Complete data sets can now be utilized for scientific reports and reviews, and special requests for sample data. Queries are performed within dBase to retrieve, organize, and display data. These are then exported into either an ASCII file or a spreadsheet file for data reduction. Generation of isotope data tables for ${ }^{137} \mathrm{Cs},{ }^{90 \mathrm{Sr}},{ }^{239+240} \mathrm{Pu}$ and ${ }^{241} \mathrm{Am}$ are routinely done for each island and sample type collected. Statistical evaluations are performed on these data sets and the summaries are used for island characterization, diet tables, and dose assessments. Other MI data organized for statistical evaluation and summarization are for the studies conducted on concentration ratios (CR's), remedial measures for reducing ${ }^{137} \mathrm{Cs}$ uptake in vegetation and environmental half-life.

\section{Characterization}

Radiological conditions are studied at all islands and atolls where samples have been collected. Queries are made in dBase to retrieve data for a specific island, atoll, isotope and sample type. These data are exported into an ASCII file referred to as an isotope data table. The isotopes for ${ }^{137} \mathrm{Cs},{ }^{90} \mathrm{Sr}, 239+240 \mathrm{Pu}$ and ${ }^{241} \mathrm{Am}$ are routinely generated for each island, atoll and sample type collected. A FORTRAN program for statistical evaluation is run on each isotope data table producing an isotope data summary. Additional isotopes are summarized as necessary. These isotope data summaries are used in characterization. 


\section{Dose Assessments}

The isotope data summaries contain the arithmetic mean of the specific activities for each sample type collected. The specific activities are decayed to a specified date for utilization in diet tables. These tables produce the average intake of ${ }^{137} \mathrm{Cs},{ }^{90} \mathrm{Sr}$, $239+240 \mathrm{Pu}$ and ${ }^{241} \mathrm{Am}$ from local foods. These data parameters are used for the ingestion pathway in predicting radiological dose. A dose assessment via the external, inhalation and ingestion pathways are estimated for various living conditions. The radiological dose assessment is calculated using a FORTRAN program which produces the maximum annual effective dose and the 30,50 and 70 year integral effective dose. The maximum annual organ equivalent dose for external gamma, ingestion, and inhalation is also produced. Dose assessments have been done at Bikini Atoll as discussed in Robison 1975, 1977, 1982b, 1990, 1993. Other dose assessments have been done at Enewetak Atoll (Robison 1980, 1987), and Rongelap Atoll (Robison 1982, 1989, 1994). In 1978 a radiological survey was conducted at the atolls of Taka, Bikar, Rongerik, Ailinginae, Likiep, Ailuk, Wotho and Ujelang and the two islands of Mejit and Jemo where preliminary dose assessments were done. (Robison et al., 1982a and Noshkin 1981).

\section{Concentration Ratios}

Concentration Ratio (CR) is the ratio of the isotope value of dry plant/dry soil $(0-40 \mathrm{~cm})$ for the radionuclide of interest. CR's for ${ }^{137} \mathrm{Cs},{ }^{90} \mathrm{Sr}, 239+240 \mathrm{Pu}$ and ${ }^{241} \mathrm{Am}$ have been developed at various atolls. The same FORTRAN program for the isotope data summaries also calculates the concentration ratios for each isotope and sample type on all islands where samples were collected. Concentrations ratios developed at Bikini Island are discussed in Robison 1995a, 1995b.

\section{Remedial Measures}

Currently there are approximately fourteen experiments studying the effect of remedial measures for reducing ${ }^{137} \mathrm{Cs}$ uptake in vegetation. All data from each experiment are summarized prior to the next sampling trip. These summaries help direct the sampling plan by determining if the objectives of the experimental design are being met, and what future treatments are appropriate. Remedial Measures are discussed in Robison 1986, 1992)

\section{Environmental Half-Life}

The Environmental Half-Life of ${ }^{137} \mathrm{Cs}$ is the time required to reduce the cesium concentration by one half of the original value, by processes other than radiological decay. Summaries of ${ }^{137} \mathrm{Cs}$ are generated for individual samples taken at a specific location taken over time. 


\section{Database Programming}

The majority of the database programming has been done using the dBase programming language. Over the last nine years, the programs written for the dBase databases have evolved as the need arises. The menus and data entry screens permit control over access to the underlying databases. They allow for the use of data entry templates and automatic data fill in, eliminating many mistakes. Writing programs for procedures that are routinely repeated improves the efficiency of the data reduction efforts.

\section{Field Sample Entry}

One set of programs was written to be used in the field for sample information entry. The main menu program on the laptop computer controls the sample log book entry. It allows entry, editing and report menu options for the Sample Information database.

\section{Laboratory Sample Entry}

The main menu on the networked computers at LLNL differs from the laptop computer. The programs written for field sample entry cannot be accessed through this menu. The vegetation and soil laboratory processing data entry is controlled through this series of programs. In addition, individual programs written to accomplish a variety of tasks, such as calculating wet/dry weight ratios can be accessed from this menu.

\section{Bar Code Design}

Beginning with the first sampling trip of 1993, a bar code system was implemented to speed up data entry. Each sample can, processing carton and leftover container is given a bar code label. This ensures accuracy in entering our sample ID. There are currently five scanners attached to computers in the laboratories and offices, and a hand held scanner for use in remote locations.

The bar codes were designed with Label Matrix software, using the Code 39 symbology. The labels are printed on a thermal transfer printer using high quality label stock and adhesive. Sample information, along with the sample ID number, are printed on the label in human readable form. Only the sample ID number, or sample weight, is bar coded.

\section{Storage Location}

After a sample is analyzed, it is stored in a box in a storage transportainer on site at LLNL. Samples through 1983, excluding the marine samples, have been shipped to the Nevada Test Site for permanent storage. Because samples must occasionally be pulled 
from the storage box for recount, it is necessary to be able to locate the sample. The samples remaining in storage at $L L N L$, are inventoried in two different databases.

A dBase database, called "SHELF" contains transportainer, shelf and box number information for over 14000 sample cans. Because the samples were boxed in numerical order, the procedure of packing and cataloguing the boxes was labor intensive. To speed up the process, the decision was made to include only the box name and sample can identification number in an ASCII text file. The location of the individual boxes is being catalogued as time permits and is being imported into our dBase "SHELF" database. A simple text search can quickly locate the box name for any sample in our box list files.

Beginning in 1995, as part of our Quality Control procedures, boxes are inventoried prior to analysis. After analysis, the inventory is verified to make sure all samples have been returned to the proper box. Standards are removed to be reused and the box of samples is sent to storage. If a sample is removed from one of these boxes, a notation is made in the box list file. The number of sample boxes currently being stored at LLNL approaches 1200 . This is in addition to all residual sample container boxes.

\section{Acknowledgments}

Ensuring accurate, and reproducible data is the goal of the Marshall Islands Radioecology Project. A team effort is important to fulfill these objectives. We would like to thank the Marshall Island team for their dedication and persistence: Bill Robison, Marshall Stuart, James Brunk, Steve Kehl, Vic Noshkin, Kai Wong, Liena Wasley, Terry Jokela, Henry Jones, Steve Hall, Mike Granillo, Rusty Steele, Bob Weidmen, Mark Gaona, C.C. Cox, Christina Gomez, Peter Madrid and Jordan Brough. Bill Phillips, John Rehder, Mark Mount and others have contributed greatly in the past, and we appreciate their efforts. 


\section{References}

Brunk, J.L.(1995), Instructions for Calibrating Gamma Detectors Using the Nuclear Data Genie Gamma Spectroscopy System, Lawrence Livermore National Laboratory, Livermore, CA, UCRL-ID-120428.

Conrado, C.L., W.L. Robison, S.R. Kehl, A.C. Stoker (1995), The Marshall Islands Dose Assessment and Radioecology Quality Control Program for Gamma Spectroscopy, Lawrence Livermore National Laboratory, Livermore, CA, (In preparation).

Gunnink, R., J.B. Niday (1971), Computerized Quantitive Analysis by Gamma-Ray Spectrometry. Vol. 2. Source Listing of the Gamanal Program, Lawrence Livermore National Laboratory, Livermore, CA, UCRL-51061, Pt. 2.

Gunnink, R., J.B. Niday (1971), Computerized Quantitive Analysis by Gamma-Ray Spectrometry. Vol. 3. A User's Guide to Gamanal, Lawrence Livermore National Laboratory, Livermore, CA, UCRL-51061, Pt. 3.

Gunnink, R., J.B. Niday (1972), Computerized Quantitive Analysis by Gamma-Ray Spectrometry. Vol. 1. Description of the Gamanal Program, Lawrence Livermore National Laboratory, Livermore, CA, UCRL-51061, Pt. 1.

Kehl S.R., Mount, M.E., W.L. Robison(1995), The Northern Marshall Islands Radioecology Survey: A Quality Control Program for Radiochemical and Gamma Spectroscopy, Lawrence Livermore National Laboratory, Livermore, CA, UCRL-ID-120429.

Noshkin, V.E., R.J. Eagle, K.M. Wong, T.A. Jokela, W.L Robison (1981), Radionuclide Concentrations and Dose Assessment of Cistern Water and Groundwater at the Marshall Islands, Lawrence Livermore National Laboratory, Livermore, CA, UCRL-52853, Pt. 2.

Robison, W.L. (1990), Estimates of the Radiological Dose to People Living on Bikini Island for Two Weeks while Diving In and Around the Sunken Ships in Bikini Lagoon, Lawrence Livermore National Laboratory, Livermore, CA, UCRL-ID-104916.

Robison, W.L. and E.L. Stone (1986a), Bikini Atoll Rehabilitation Committee Report No. 4 , Status March 31, 1986. Appendix A, submitted March 31, 1986 to the U.S. Congress, House and Senate Committees on Interior Appropriations, Washington, DC, pp. A1 through A40.

Robison, W.L. and W.A. Phillips (1989), Estimates of the Radiological Dose from Ingestion of ${ }^{137} \mathrm{Cs}$ and ${ }^{90} \mathrm{Sr}$ to Infants, Children, and Adults in the Marshall Islands, Lawrence Livermore National Laboratory, Livermore, CA, UCRL-53917.

Robison, W.L., and E.L. Stone (1992), "The Effect of Potassium on the Uptake of ${ }^{137} \mathrm{Cs}$ in Food Crops Grown on Coral Soils: Coconut at Bikini Atoll," Health Phys. (62), 496-51. 
Robison, W.L., B. Clegg, and E. Stone (1986b), "Rehabilitation of Bikini Atoll: Surface Soil Removal Reduces ${ }^{137}$ Cs Contamination in Food Plants," Soil Sci. Soc. Am., Annu. Meet., New Orleans, LA.

Robison, W.L., C.L. Conrado, A.C. Stoker, M.L. Stuart (1995b), "The Concentration Ratio for Transuranic Radionuclides in Food Crops in an Atoll Carbonate Soil Ecosystem," Health Phys., Abstract (In preparation).

Robison, W.L., C.L. Conrado, K.T. Bogen (1994), An Updated Dose assessment for Rongelap Island, Lawrence Livermore National Laboratory, Livermore, CA, UCRL-LR-107036.

Robison, W.L., C.L. Conrado, M.L. Stuart, A.C. Stoker (1995a) "Concentration Ratios for ${ }^{137} \mathrm{Cs}$ and ${ }^{90} \mathrm{Sr}$ in Foods Locally Grown on Bikini Island at Bikini Atoll," Health Phys., Abstract (In preparation)

Robison, W.L., C.L. Conrado, W.A. Phillips (1987), Enjebi Island Dose Assessment, Lawrence Livermore National Laboratory, Livermore, CA, UCRL-53805.

Robison, W.L., K.T. Bogen, C.L. Conrado (1993), "A Dose Assessment for a U.S. Nuclear Test Site-Bikini Atoll," Proceedings of the Special Plenary Session at 5th VAMP RCM Meeting, July 5-9, 1993, International Atomic Energy Agency (IAEA), Vienna, Austria, UCRL-JC-115100.

Robison, W.L., M.E. Mount, W.A. Phillips, C.L. Conrado, M.L. Stuart, A.C. Stoker (1982a), The Northern Marshall Islands Radiological Survey: Terrestrial Food Chain and Total Doses, Lawrence Livermore National Laboratory, Livermore, CA, UCRL-52853, Pt. 4.

Robison, W.L., M.E. Mount, W.A. Phillips, M.L. Stuart, S.E. Thompson, C.L. Conrado, A.C. Stoker (1982b), An Updated Radiological Dose Assessment of Bikini and Eneu Islands at Bikini Atoll, Lawrence Livermore National Laboratory, Livermore, CA, UCRL-53225.

Robison, W.L., W.A. Phillips, C.S. Colsher (1977), Dose Assessment at Bikini Atoll, Lawrence Livermore National Laboratory, Livermore, CA, UCRL-51879, Pt. 5.

Robison, W.L., W.A. Phillips, M.E. Mount, B.R. Clegg, C.L. Conrado (1980), Reassessment of the Potential Radiological Doses for Residents Resettling Enewetak Atoll, Lawrence Livermore National Laboratory, Livermore, CA, UCRL-53066.

Robison, W.L., Y.C. Ng, S.E. Thompson, and W.A. Phillips (1975), Bikini Dose Assessment, report to AEC H.Q.

Stuart, M.L. (1995), Field Collection and Laboratory Sample Processing Procedures for the Marshall Islands Program, Lawrence Livermore National Laboratory, Livermore, CA, UCRL-ID-120427. 
Appendix A: Commercial Software in Use in Data Management Program 
The following software programs are currently in use in the Marshall Islands Data Management Program:

Microsoft Excel ${ }^{\circledR}$, Symphony ${ }^{\circledR}$, Microsoft Word $®$, Synergy Software's Kaleidograph, StrandWare's Label Matrix, Flexible Information Systems, Inc.'s Label Vision, Traveling Software's Laplink, DataViz MacLink Plus, Microsoft PowerPoint, High Performance Systems IThink and Claris Draw. The following programming languages are in use: dBase, and Microsoft FORTRAN. 
Appendix B: Island and Atoll Designation Codes 
Table B-1. Islands of Bikini Atoll.

Island \&

Atoll Code $00 \mathrm{~B}$

01B

02B

03B

04B

05B

06B

07B

$08 \mathrm{~B}$

09B

$10 \mathrm{~B}$

$11 \mathrm{~B}$

$12 B$

$13 \mathrm{~B}$

14B

$15 \mathrm{~B}$

$16 \mathrm{~B}$

17B

18B

$19 \mathrm{~B}$

20B

21B

22B

23B

45B

$46 B$

47B

48B

$49 \mathrm{~B}$

$55 \mathrm{~B}$

$56 \mathrm{~B}$

Island \&

\begin{tabular}{cc} 
Field Code & Marshallese Name \\
\hline B0 & No Island Name \\
BN & Nam
\end{tabular}

BI

BOD

BLK

BAM

BB

BBN

BLM

BEL

BR

BEJ

BE

BAR

BBK

BLL

BEN

BED

BLJ

BJ

BAD

BOR

BBT

BBD

BBC

$\mathrm{BL}$

BO

BBR

BR

BTC

BZC

Nam

Iroij

Odrik

Lomilik

Aomen

Bikini

Bokantauk

Lomelen

Enealo

Rojkere

Eonjebi

Eneu

Aerokojlol

Bikdrin

Lele

Eneman

Enidrik

Lukoj

Jelete

Adrikan

Oroken

Bokaetoktok

Borkdrlul

Bravo Crater

Bikini Lagoon

Bikini Ocean

Boro Reef

Bikini Reef

Tewa Carter

Zuni Crater

U.S. Code Name Japanese Name

Charlie

Dog

Easy

Fox

George

How

Item

Jig

King

Love

Mike

Nan

Peter

Roger

Sugar

Tare

Uncle

Victor

William

Yoke

Zebra

Alpha

Bravo
Namu

Yurochi

Yorikku

Romurikku

Aomeon

Bikini

Bokonfaaku

Yomyaran

Eniairo

Rochikarai

Ionchebi

Enyu

Airukiraru

Bigiren

Reere

Eniman

Enirik

Rukoji

Chieerete

Arrikan

Ourukaen

Bokoaetokutoka

Bokororyuru

Islands of Enewetak Atoll

Atoll Code

OOE

$01 \mathrm{E}$

02E

$03 \mathrm{E}$

$04 \mathrm{E}$

05E

$06 \mathrm{E}$

Field Code

Marshallese Name

U.S. Code Name Japanese Name

No Island Name

E0

Bokoluo

Alice

EB

Bokombako

Belle

ECL

ED

EED

Kirunu

Clara

Ruchi

Daisy

Cochiti

Bocinwotme

Edna

EFR

N.E. of Bocinwotme

Flora 
Table B-1. Islands of Bikini Atoll continued.

Island \& Atoll Code Field Code Marshallese Name

OTE

$08 \mathrm{E}$

09E

$10 \mathrm{E}$

$11 \mathrm{E}$

$12 \mathrm{E}$

$13 \mathrm{E}$

$14 \mathrm{E}$

$15 \mathrm{E}$

$16 \mathrm{E}$

$17 \mathrm{E}$

$18 \mathrm{E}$

$19 \mathrm{E}$

$20 \mathrm{E}$

$21 \mathrm{E}$

$22 \mathrm{E}$

$23 \mathrm{E}$

24E

$25 \mathrm{E}$

26E

27E

$28 \mathrm{E}$

29E

$30 \mathrm{E}$

$31 \mathrm{E}$

$32 \mathrm{E}$

$33 \mathrm{E}$

$34 \mathrm{E}$

$35 \mathrm{E}$

$36 \mathrm{E}$

$37 \mathrm{E}$

$38 \mathrm{E}$

$39 \mathrm{E}$

$40 \mathrm{E}$

$41 \mathrm{E}$

$42 \mathrm{E}$

$43 \mathrm{E}$

$44 \mathrm{E}$

$45 \mathrm{E}$

$46 \mathrm{E}$

$47 \mathrm{E}$

$48 \mathrm{E}$
EGN

EHL

EI

EJ

EKT

ELC

EPC

EMR

ENC

EO

EP

ERB

ES

ET

EU

EV

EWL

EY

EZ

ESM

ETM

EUR

EVN

EAV

EBR

ECY

EDV

ERX

EE

EW

EF

EGL

EHR

EIR

EJM

EKH

ELR

EMC

EOS

ENH

EWP

EDP
Dridrilbwij

Bokaidrikdrik

Boken

Enjebi

Mijikadrek

Kidrinen

Taiwel

Bokenelab

Elle

Aej

Lujor

Eleleron

Aomen

Bijire

Lojwa

Alembel

Billae

Runit

Runit-Southern

Boko

Munjor

Inedral

Jinedrol

Ananij

Jinimi

Japtan

Jedrol

Medren

Bokandretok

Enewetak

Ikuren

Mut

Boken

Ribewon

Kidrenen

Biken

Unibor

Drekatimon

Wide Passage

Deep Passage
U.S. Code Name Japanese Name

Gene

Helen

Irene

Janet

Kate

Lucy

Percy

Mary

Nancy

Olive

Pearl

Ruby

Salley

Tilda

Ursula

Vera

Wilma

Yvonne

Zona

Sam

Tom

Uriah

Van

Alvin

Bruce

Clyde

David

Rex

Elmer

Walt

Fred

Glenn

Henry

Irwin

James

Keith

Leroy

Mack

Oscar

Noah

Wide Passage

Deep Passage
Teiteiripucchi

Bogairikk

Mujinikaroku

Kirinian

Bokonaarappu

Rujoru

Aaraanbiru

Piiraar

Aniyaanii

Jieroru

Ikurin

Ribaion

Giriinien 
Table B-1. Islands of Bikini Atoll continued.

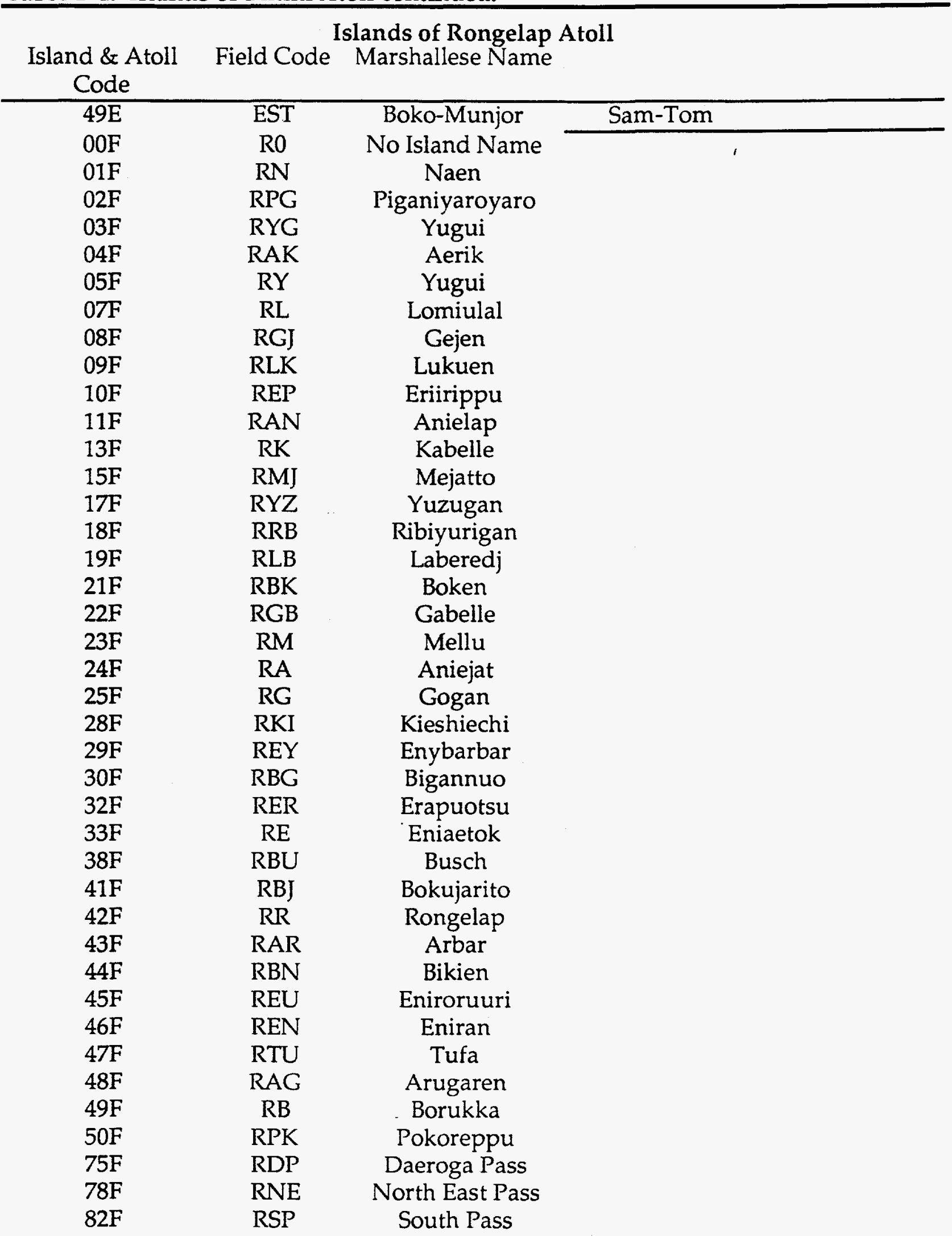


Table B-1. Islands of Bikini Atoll continued.

Island \&

Islands of Rongelap Atoll continued

Atoll Code Field Code Marshallese Name U.S. Code Name Japanese Name

$\begin{array}{lll}83 \mathrm{~F} & \text { RWP } & \text { West Pass } \\ 82 \mathrm{~F} & \text { RSP } & \text { South Pass } \\ 83 \mathrm{~F} & \text { RWP } & \text { West Pass }\end{array}$

Island \&

Islands of Kwajalein Atoll

Atoll Code Field Code Marshallese Name

\begin{tabular}{lcc}
\hline $00 \mathrm{~K}$ & $\mathrm{KO}$ & No Island Name \\
$86 \mathrm{~K}$ & $\mathrm{KR}$ & Roi-Namur \\
$87 \mathrm{~K}$ & $\mathrm{KED}$ & Edgigen \\
$88 \mathrm{~K}$ & $\mathrm{~KB}$ & Biggeran \\
$89 \mathrm{~K}$ & $\mathrm{KG}$ & Geiga \\
$90 \mathrm{~K}$ & $\mathrm{KN}$ & Nelle \\
$91 \mathrm{~K}$ & $\mathrm{KEB}$ & Ebadon \\
$92 \mathrm{~K}$ & $\mathrm{KK}$ & Kwajalein \\
$93 \mathrm{~K}$ & $\mathrm{KI}$ & Illiginni
\end{tabular}

Island \&

Islands of Majuro Atoll

Atoll Code Field Code Marshallese Name

\begin{tabular}{ccc}
\hline $01 \mathrm{Q}$ & $\mathrm{MM}$ & Majuro \\
$02 \mathrm{Q}$ & $\mathrm{ME}$ & Enemanet \\
$03 \mathrm{Q}$ & $\mathrm{MEN}$ & Eneko
\end{tabular}

Island \& Atoll

Islands of Utirik Atoll

Code

Field Code Marshallese Name

\begin{tabular}{ccc} 
Code & Field Code & Marshallese Name \\
\hline 001 & U0 & No Island Name \\
01 II & UPJ & Piji \\
02 I & UE & Eerukku \\
03 I & UP & Pigowak \\
$04 \mathrm{I}$ & UM & Maaje \\
$06 \mathrm{I}$ & UU & Utirik \\
$08 \mathrm{I}$ & UA & Aon
\end{tabular}


Table B-1. Islands of Bikini Atoll continued.

Island \&

Islands of Rongerik Atoll

Atoll Code

Field Code Marshallese Name

\begin{tabular}{lcc}
\hline $00 G$ & G0 & No Island Name \\
$01 G$ & GJ & Jedibberdib \\
$02 G$ & GL & Latoback \\
$03 G$ & GMT & Moterikku \\
$04 G$ & GMR & Mortlock \\
$05 G$ & GBG & Bigonattam \\
$06 G$ & GR & Rongerik \\
$09 G$ & GT & Tarrowatt \\
$10 G$ & GBK & Bokeredj \\
$11 G$ & GE & Eniwetak \\
$12 G$ & GBC & Bock
\end{tabular}

Islands of Ailinginae Atoll

Island \& Atoll Field Code Marshallese Name

Code

\begin{tabular}{|c|c|c|}
\hline $00 \mathrm{C}$ & $\mathrm{CO}$ & No Island Name \\
\hline $01 C$ & $\mathrm{CN}$ & Najibuen \\
\hline $02 \mathrm{C}$ & CBI & Bokoikaiaru \\
\hline $04 \mathrm{C}$ & $\mathrm{CC}$ & Charaien \\
\hline $05 C$ & CBR & Bokoryuren \\
\hline $08 \mathrm{C}$ & $\mathrm{CMJ}$ & Majokoryaan \\
\hline 09C & CBE & Bokoen \\
\hline $10 \mathrm{C}$ & CKX & Knox \\
\hline $11 C$ & CKN & Kungeekan \\
\hline $13 C$ & CBN & Bokanchinre \\
\hline $15 C$ & $\mathrm{CU}$ & Ucchuwanen \\
\hline $16 C$ & $\mathrm{CP}$ & Pigessharukku \\
\hline $18 \mathrm{C}$ & CKB & Kuobuen \\
\hline $19 \mathrm{C}$ & CR & Ribinouri \\
\hline $20 C$ & $\mathrm{CA}$ & Airuken \\
\hline $22 \mathrm{C}$ & CET & Eniuetakku \\
\hline $23 C$ & CEB & Enibuk \\
\hline $24 C$ & CMG & Mogiri \\
\hline $25 \mathrm{C}$ & CMN & Manchinikson \\
\hline $27 \mathrm{C}$ & CS & Sifo \\
\hline
\end{tabular}


Table B-1. Islands of Bikini Atoll continued.

\section{Islands of Ailuk Atoll}

Island \& Atoll

Code

$00 \mathrm{~A}$

$01 \mathrm{~A}$

$02 \mathrm{~A}$

$04 \mathrm{~A}$

$07 \mathrm{~A}$

$09 \mathrm{~A}$

$10 \mathrm{~A}$

$11 \mathrm{~A}$

$12 \mathrm{~A}$

$13 \mathrm{~A}$

$14 \mathrm{~A}$

$17 \mathrm{~A}$

$19 \mathrm{~A}$

$20 \mathrm{~A}$

$24 \mathrm{~A}$

$27 \mathrm{~A}$

$28 \mathrm{~A}$

29A

$31 \mathrm{~A}$

$33 \mathrm{~A}$

$35 \mathrm{~A}$

$37 \mathrm{~A}$

$38 \mathrm{~A}$

$41 \mathrm{~A}$

$42 \mathrm{~A}$

$44 \mathrm{~A}$

$46 \mathrm{~A}$

$47 \mathrm{~A}$

$48 \mathrm{~A}$

$49 \mathrm{~A}$

$51 \mathrm{~A}$

$52 \mathrm{~A}$

$53 \mathrm{~A}$
Field Code Marshallese Name

$\mathrm{AO} \quad$ No Island Name

AKP Kapen

AEB Enijabro

AEL Enejelar

$A B G$

AEM

AAC

AAI

AAR

AER

AEK

AKB

AMK

AAL

AS

ABJ

AR

ABK

ABI

ABR

AT

AKN

AC

$\mathrm{AU}$

AMP

AEG

AEA

AEE

AEN

AY

AA

AEJ

AAG
Bigen

Eneneman

Achaatakku

Ajeleb

Ajirikku

Enearumichi

Enenekugi

Kabbo

Marokku

Aliet

Shurongan

Bauejin

Rujerukku

Bekerappu

Bio

Bererjao

Tabu

Kanon

Chiebeiku

Uriga

Maruppu

Eninikugi

Enoa

Eneao

Enemaneman

Yappui

Ailuk

Enije

Agulue 
Table B-1. Islands of Bikini Atoll continued.

Island \&

Islands of Likiep Atoll

Atoll Code Field Code Marshallese Name

$\begin{array}{lcc}\text { 00L } & \text { LO } & \text { No Island Name } \\ 01 \mathrm{~L} & \text { LMO } & \text { Mato } \\ 02 \mathrm{~L} & \text { LRR } & \text { Rikuraru } \\ 03 \mathrm{~L} & \text { LMR } & \text { Mere } \\ 04 \mathrm{~L} & \text { LPC } & \text { Pokonchieichi } \\ \text { 05L } & \text { LKG } & \text { Kerenegan } \\ 06 \mathrm{~L} & \text { LEO } & \text { Eninon } \\ 07 \mathrm{~L} & \text { LAP } & \text { Aapuran } \\ 08 \mathrm{~L} & \text { LEC } & \text { Enechieraru } \\ 10 \mathrm{~L} & \text { LKB } & \text { Kaben } \\ 11 \mathrm{~L} & \text { LEN } & \text { Eneneman } \\ 12 \mathrm{~L} & \text { LER } & \text { Enrukku } \\ 13 \mathrm{~L} & \text { LJL } & \text { Jeltonet } \\ 14 \mathrm{~L} & \text { LPK } & \text { Pikenmenmenchaien } \\ 15 \mathrm{~L} & \text { LBK } & \text { Bikkenimenshaiarekko } \\ 16 \mathrm{~L} & \text { LBG } & \text { Boguraburabu } \\ 18 \mathrm{~L} & \text { LKJ } & \text { Kejien } \\ 20 \mathrm{~L} & \text { LTM } & \text { Tamori } \\ 21 \mathrm{~L} & \text { LKK } & \text { Kaberuberukan } \\ 25 \mathrm{~L} & \text { LN } & \text { Nachibaru } \\ 26 \mathrm{~L} & \text { LEI } & \text { Eniiecchi } \\ 27 \mathrm{~L} & \text { LKM } & \text { Kirenmaru } \\ \text { 28L } & \text { LMN } & \text { Meron } \\ 30 \mathrm{~L} & \text { LJB } & \text { Jiebaru } \\ 31 \mathrm{~L} & \text { LKE } & \text { Kere } \\ 32 \mathrm{~L} & \text { LKI } & \text { Kire } \\ 34 \mathrm{~L} & \text { LBB } & \text { Biebi } \\ 35 \mathrm{~L} & \text { LMK } & \text { Mukkuri } \\ 36 \mathrm{~L} & \text { LLD } & \text { Lado } \\ 37 \mathrm{~L} & \text { LL } & \text { Likiep } \\ 40 \mathrm{~L} & \text { LEW } & \text { Enenuuwan } \\ 45 \mathrm{~L} & \text { LAG } & \text { Agony } \\ 46 \mathrm{~L} & \text { LET } & \text { Entrance } \\ 47 \mathrm{~L} & \text { LEL } & \text { Etoile } \\ 50 \mathrm{~L} & \text { LLK } & \text { Lukunor } \\ 52 \mathrm{~L} & \text { LAN } & \text { Aaneru } \\ 53 \mathrm{~L} & \text { LTK } & \text { Tokaen } \\ 54 \mathrm{~L} & \text { LMT } & \text { Matten } \\ 55 \mathrm{~L} & \text { LKP } & \text { Kapenor } \\ & & \\ & & \end{array}$


Table B-1. Islands of Bikini Atoll continued.

Island \&

Atoll Code

Field Code Marshallese Name U.S. Code Name Japanese Name

Islands of Likiep Atoll continued

$56 \mathrm{~L}$

LBL

$57 \mathrm{~L}$

LRG

$58 \mathrm{~L}$

LRK

Bokelan

Rongelap

Rongerik

Island \&

Islands of Ujelang Atoll

Atoll Code

Field Code

Marshallese Name

\begin{tabular}{lcc}
\hline $00 \mathrm{~J}$ & J0 & No Island Name \\
$01 \mathrm{~J}$ & JPY & Pyokon \\
$02 \mathrm{~J}$ & JBG & Boggelininlapp \\
$04 \mathrm{~J}$ & JS & Seroko \\
$05 \mathrm{~J}$ & JPK & Pokon \\
$08 \mathrm{~J}$ & JKG & Kilagen \\
$15 \mathrm{~J}$ & JM & Maron \\
$17 \mathrm{~J}$ & JD & Daisu \\
$18 \mathrm{~J}$ & JU & Ujelang \\
$20 \mathrm{~J}$ & JBL & Burle \\
$21 \mathrm{~J}$ & JR & Ronu \\
$22 \mathrm{~J}$ & JEL & Eimnlapp \\
$23 \mathrm{~J}$ & JEN & Ennimenetto \\
$24 \mathrm{~J}$ & JKR & Kiriniyan \\
$25 \mathrm{~J}$ & JKL & Kalo
\end{tabular}

Island \&

Islands of Taka Atoll

Atoll Code

Field Code Marshallese Name

$\begin{array}{ccc}00 \mathrm{H} & \text { T0 } & \text { No Island Name } \\ 01 \mathrm{H} & \text { TW } & \text { Waatowerikku } \\ 03 \mathrm{H} & \text { TR } & \text { Raajerun } \\ 04 \mathrm{H} & \text { TT } & \text { Taka } \\ 05 \mathrm{H} & \text { TE } & \text { Eluk }\end{array}$


Table B-1. Islands of Bikini Atoll continued.

Island \&

\section{Islands of Bikar Atoll}

Atoll Code

Field Code Marshallese Name

OOD

DO No Island Name

01D DJK Jaboerukku

02D DA Arumenii

03D DJB Jaboero

04D DB Bikar

Island \&

Islands of Wotho Atoll

Atoll Code

Field Code Marshallese Name

00M WO No Island Name

$01 \mathrm{M}$

$02 \mathrm{M}$

WMD

WWR

Medyeron

$03 \mathrm{M}$

WMK

$04 \mathrm{M}$

$12 \mathrm{M}$

$13 \mathrm{M}$

$14 \mathrm{M}$

$15 \mathrm{M}$

$16 \mathrm{M}$

$17 \mathrm{M}$

$18 \mathrm{M}$

$19 \mathrm{M}$

20M

WW

WR

WJ

WU

WET

WY

WK

WER

Worrbar

Mokeromok

Wotho

Ruisuwaa

Jebenau

Uditi

Erotjeman

Yeldo

Kabben

WO

Eirek

Ombelim

WB

Begin

Island \&

Islands of Mejit And Jemo

Atoll Code

Field Code

Marshallese Name

01R

MEJ

Mejit

$01 S$

JEM

Jemo 
Appendix C: Sample Type Designation Codes 
Table C-1. Designation codes.

\begin{tabular}{|c|c|c|}
\hline AIA & Aquatic Invertebrate & Mantle \\
\hline AIC & Aquatic Invertebrate & Gut Content \\
\hline AID & Aquatic Invertebrate & Cephalothorax \\
\hline AIE & Aquatic Invertebrate & Remains \\
\hline AIF & Aquatic Invertebrate & Gills \\
\hline AIG & Aquatic Invertebrate & Digestive Gland \\
\hline AIH & Aquatic Invertebrate & Hepatopancreas \\
\hline $\mathrm{AIJ}$ & Aquatic Invertebrate & Cooking Juice \\
\hline AIK & Aquatic Invertebrate & Kidney \\
\hline AIL & Aquatic Invertebrate & Liver \\
\hline AIM & Aquatic Invertebrate & Muscle \\
\hline AIN & Aquatic Invertebrate & Shell/Integument \\
\hline AIP & Aquatic Invertebrate & Valve \\
\hline AIR & Air Sample & Filter \\
\hline AIS & Aquatic Invertebrate & Soft Parts \\
\hline AIT & Aquatic Invertebrate & Eggs \\
\hline AIV & Aquatic Invertebrate & Viscera \\
\hline AIX & Aquatic Invertebrate & Exoskeleton/Integument \\
\hline AIZ & Aquatic Invertebrate & Whole Sample \\
\hline ALG & Algea & Algea \\
\hline DPF & Distillation & Plant Filters \\
\hline DPW & Distillation & Plant Water \\
\hline ENV & Environmental Sample & Environmental Sample \\
\hline FAR & Fish & Intestine/Stomach \\
\hline FBR & Fish & Bone \\
\hline FCR & Fish & Stomach Contents \\
\hline FFR & Fish & Gills \\
\hline FGR & Fish & Gizzard \\
\hline FIR & Fish & Intestinal Contents \\
\hline FLR & Fish & Liver \\
\hline FMR & Fish & Muscle \\
\hline FNR & Fish & Skin/Scales \\
\hline FRR & Fish & Gonads-Testes \& Ovary \\
\hline FSH & Fish & Sample \\
\hline FSR & Fish & Spleen \\
\hline FVR & Fish & Viscera \\
\hline FZR & Fish & Entire Fish \\
\hline LIA & Land Invertebrate & Mantle \\
\hline LIC & Land Invertebrate & Gut Content \\
\hline LID & Land Invertebrate & Cephalothorax \\
\hline LIE & Land Invertebrate & Remains \\
\hline LIF & Land Invertebrate & Gills \\
\hline
\end{tabular}


Table C-1. Designation codes continued.

\begin{tabular}{|c|c|c|}
\hline Sample Type & & cription \\
\hline LIG & Land Invertebrate & Digestive Gland \\
\hline LIH & Land Invertebrate & Hepatopancreas \\
\hline LIJ & Land Invertebrate & Cooking Juice \\
\hline LIK & Land Invertebrate & Kidney \\
\hline LIL & Land Invertebrate & Liver \\
\hline LIM & Land Invertebrate & Muscle \\
\hline LIN & Land Invertebrate & Shell/Integument \\
\hline LIP & Land Invertebrate & Valve \\
\hline LIS & Land Invertebrate & Soft Parts \\
\hline LIT & Land Invertebrate & Eggs \\
\hline LIV & Land Invertebrate & Viscera \\
\hline LIX & Land Invertebrate & Exoskeleton \\
\hline LIZ & Land Invertebrate & Whole \\
\hline LVD & Birds & Eggshells \\
\hline LVE & Birds & Eggs, Hard Boiled \\
\hline MAR & Mammal & Small Intestine/Stomach \\
\hline MBR & Mammal & Bone \\
\hline MCR & Mammal & Cartilage \\
\hline MFR & Mammal & Fat \\
\hline MGR & Mammal & Lymphatic Gland \\
\hline MHR & Mammal & Heart \\
\hline MKR & Mammal & Kidney \\
\hline MMR & Mammal & Muscle/Tissue \\
\hline MNR & Mammal & Skin \\
\hline MPR & Mammal & Head \\
\hline MQR & Mammal & Hindquarter \\
\hline MRR & Mammal & Reproductive Tract \\
\hline MSR & Mammal & Spleen \\
\hline MTR & Mammal & Sternum \\
\hline MUR & Mammal & Lungs \\
\hline MVR & Mammal & Liver \\
\hline MXR & Mammal & Gizzard \\
\hline MZR & Mammal & Whole \\
\hline P01 & Plant & Portulaca \\
\hline P02 & Plant & Arrowroot Tubers/Corms \\
\hline P03 & Plant & Coconut Shell \\
\hline P04 & Plant & Coconut Husk \\
\hline P05 & Plant & Coconut Husk, Shell \& Meat \\
\hline P06 & Plant & Bark (from any species) \\
\hline P07 & Plant & Taro Root \\
\hline P08 & Plant & Taro Fruit/Meat \\
\hline P09 & Plant & Orange Meat \\
\hline P10 & Plant & Manioc \\
\hline
\end{tabular}


Table C-1. Designation codes continued.

Sample Type

P11

P12

P13

P14

P15

P16

P17

P20

P21

P22

P23

$\mathrm{P} 24$

P25

P26

P27

P28

P29

P30

P31

P32

P33

P34

P35

P36

P37

P38

P39

P40

P41

P42

P43

P44

P45

P46

P47

P48

P49

P50

P51

P52

P53

P54

P55
Plant

Plant

Plant

Plant

Plant

Plant

Plant

Plant

Plant

Plant

Plant

Plant

Plant

Plant

Plant

Plant

Plant

Plant

Plant

Plant

Plant

Plant

Plant

Plant

Plant

Plant

Plant

Plant

Plant

Plant

Plant

Plant

Plant

Plant

Plant

Plant

Plant

Plant

Plant

Plant

Plant

Plant

Plant
Description

Puraka Root

Cocao Bean Seeds

Potato Meat

Potato Skin

Orange Peels

Grapefruit Meat

Grapefruit Peels

Whole Copra Nut

Whole Coconut

Whole Pandnaus

Whole Breadfruit

Whole Papaya

Whole Banana

Whole Squash

Tacca

Whole Watermelon

Whole Sweet Potato

Whole Yam

Whole Morinda

Whole Arrowroort

Whole Taro

Whole Orange

Whole Potato

Whole Grapefruit

Zucchini Meat

Zucchini Skin

Corn Kernels

Corn Cobs

Corn Husks

Corn Stalks

Wing Bean Meat

Wing Bean Skin

Bush Bean Meat

Bush Bean Skin

Yard Long Beans

Wetak Squash Meat

Wetak Squash Skin

Wetak Squash Seeds

Chinese Cabbage

Acorn Squash Meat

Acorn Squash Skin

Acorn Squash Seeds

Zucchini Seeds 
Table C-1. Designation codes continued.

Sample Type

P56

P57

P58

P59

P60

P61

P62

P63

P64

P65

P66

P67

P68

P69

P70

P71

P72

P73

P74

P75

P76

P77

P78

P79

P80

P81

P82

P83

P84

P85

P86

P87

P88

P89

P90

P91

P92

P93

P94

PBR

PDR

PFO

PF1

\section{Plant}

Plant

Plant

Plant

Plant

Plant

Plant

Plant

Plant

Plant

Plant

Plant

Plant

Plant

Plant

Plant

Plant

Plant

Plant

Plant

Plant

Plant

Plant

Plant

Plant

Plant

Plant

Plant

Plant

Plant

Plant

Plant

Plant

Plant

Plant

Plant

Plant

Plant

Plant

Plant

Plant

Plant

Plant
Description

Sweet Potato Vines

Alfalfa

Cucumber Meat

Cucumber Skin

Cucumber Seeds

Okra

Whole Sorghum

Millet

Squash Vines

Lime Meat

Lime Skin

Lime Seeds

Lime Juice

Tabero Fruit

Lemon Meat

Lemon Skin

Lemon Seeds

Morinda Skin

Juice from Chinese Cabbage

Tomato

Bell Pepper Meat

Bell Pepper Seeds

Okra Meat

Okra Seeds

Mok-Mok Water

Mok-Mok Starch

Small Corn Ear

Palm Heart

Tapioca Meat

Tapioca Skin

S-Pepper Meat

S-Pepper Seeds

Eggplant Meat and Seeds

Eggplant Skin

Sorghum Stover

Sorghum Seed Heads

Pineapple Skin/Tops

Pineapple Meat

Collard Greens

Wood 3-" (any species)

Wood 1-3" (any species)

Watermelon Seeds

Watermelon Juice 
Table C-1. Designation codes continued.

\begin{tabular}{|c|c|c|}
\hline Sample Type & \multicolumn{2}{|c|}{ Description } \\
\hline PF2 & Plant & Sweet Potato/Yam Meat \\
\hline PF3 & Plant & Sweet Potato/Yam Skin' \\
\hline PF4 & Plant & Breadfruit Seeds \\
\hline PF5 & Plant & Pandnaus Aerial Root Meat \\
\hline PF6 & Plant & Pandnaus Aerial Root Skin \\
\hline PF7 & Plant & Copra Cream/Coconut Milk \\
\hline PF8 & Plant & Morinda Meat \\
\hline PFA & Plant & Copra Meat \\
\hline PFB & Plant & Copra Juice \\
\hline PFC & Plant & Copra Oil \\
\hline PFD & Plant & Drinking Coconut Meat \\
\hline PFE & Plant & Drinking Coconut Juice \\
\hline PFF & Plant & Sprouting Coconut-Sprouted \\
\hline PFG & Plant & Sprouting Coconut-Mature Meat \\
\hline PFH & Plant & Jakeroo Juice \\
\hline PFI & Plant & Pandnaus Meat \\
\hline PFJ & Plant & Pandnaus Juice \\
\hline PFK & Plant & Breadfruit Meat \\
\hline PFL & Plant & Breadfruit Skin \\
\hline PFM & Plant & Papaya Meat \\
\hline PFN & Plant & Papaya Skin \\
\hline PFO & Plant & Papaya Seeds \\
\hline PFP & Plant & Banana Meat \\
\hline PFQ & Plant & Banana Skin \\
\hline PFR & Plant & Miscellaneous Plant Sample \\
\hline PFS & Plant & Pumpkin Squash Meat \\
\hline PFT & Plant & Pumpkin Squash Skin \\
\hline PFU & Plant & Pumpkin Squash Seeds \\
\hline PFV & Plant & Tacca Meat \\
\hline PFW & Plant & Tacca Skin \\
\hline PFX & Plant & Tacca Corm \\
\hline PFY & Plant & Watermelon Meat \\
\hline PFZ & Plant & Watermelon Skin \\
\hline PGR & Plant & Twigs/Stalks \\
\hline PHR & Plant & Humus \\
\hline PIR & Plant & Flower \\
\hline PKT & Plant & Plankton \\
\hline PLR & Plant & Leaves/Fronds \\
\hline PRR & Plant & Roots(from any species) \\
\hline PSR & Plant & Grass \\
\hline PTR & Plant & Litter \\
\hline PVR & Plant & Fallen Leaves \\
\hline PWR & Plant & Wood 0-1" (any species) \\
\hline
\end{tabular}


Table C-1. Designation codes continued.

\begin{tabular}{cll}
\hline \multicolumn{1}{c}{ Sample Tvpe } & & Description \\
\cline { 1 - 3 } PYR & Plant & Yellow Leaves \\
PZR & Plant & Dead Wood \\
SDR & Soil & Soil Sediment \\
SHA & Ship Parts & Algae \& Rust \\
SHE & Ship Parts & Electrical Wire \\
SHP & Ship Parts & Metal \\
SHR & Soil & Humic Soil \\
SHW & Ship Parts & Wood \\
SPR & Soil & Soil Profile \\
SSR & Soil & Surface Soil \\
SWR & Soil & Leached Soil \\
WCR & Water & Cistern Water \\
WDR & Water & Pond Water \\
WER & Water & Well Water \\
WFR & Water & Water Filter \\
WLR & Water & Lysimeter Water \\
WMR & Water & Miscellaneous Water Sample \\
WNR & Water & Lens Water \\
WPR & Water & Pit Water \\
WTR & Water & Tap Water \\
WWR & Water & Rain Water \\
& &
\end{tabular}


Appendix D: Experiment Names

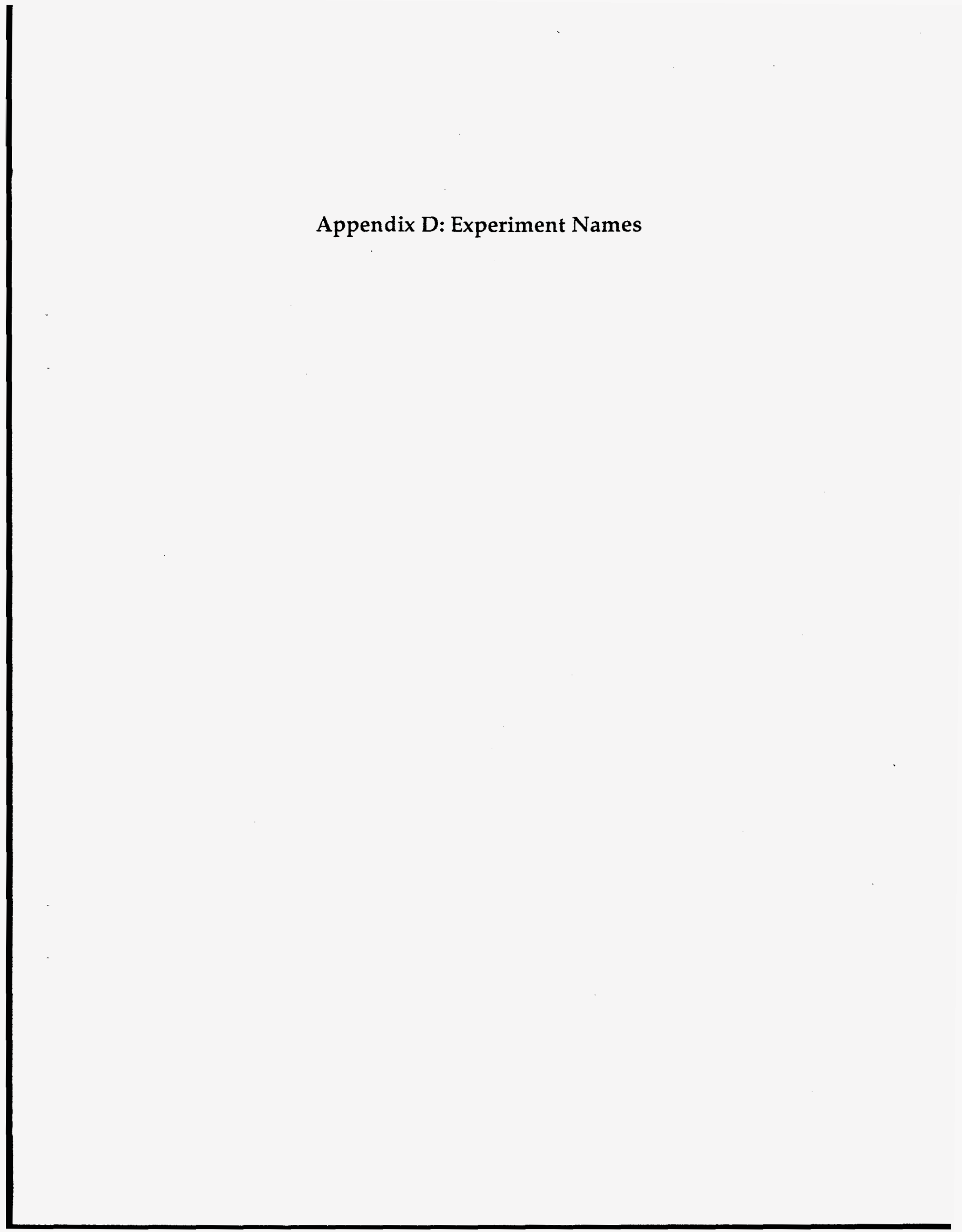


Table D-1. Experiment names.

\begin{tabular}{|c|c|c|c|c|}
\hline Bikini Atoll & Enewetak Atoll & Rongelap Atoll & Utirik Atoll & Others \\
\hline ACS PLOT & EB T1/2 & LLNL-RA & UU GRID & LLNL-MM \\
\hline CEE PLOT & $\mathrm{ED} \mathrm{T} 1 / 2$ & LLNL-RAR & UA GRID & LLNL-CMG \\
\hline CF PLOT & EDV GRID & LLNL-RB & UP GRID & LLNL-CEB \\
\hline CLC PLOT & EE GRID & LLNL-RBK & LLNL-UE & LLNL-CKX \\
\hline CLINO & EF GRID & LLNL-RBU & & LLNL-KK \\
\hline ELS PLOT & EF GRID & LLNL-RE & & \\
\hline ENEU GDN & EI T1/2 & LLNL-REN & & \\
\hline ENEU GRID & EJ T1 $/ 2$ & LLNL-RER & & \\
\hline EXXCONT & ENJEBI GDN & LLNL-RG & & \\
\hline EXX PLOT & EV GRID & LLNL-RGB & & \\
\hline HEJ PLOT & LEO'S GDN & LLNL-RI & & \\
\hline HIGH K & LLNL-E0 & LLNL-RK & & \\
\hline HIGHK CONT & LLNL-EB & LLNL-RL & & \\
\hline ION PEN & LLNL-EF & LLNL-RM & & \\
\hline IPE & LLNL-EJ & LLNL-RN & & \\
\hline IRRIG CONT & LLNL-EM & LLNL-RR & & \\
\hline IRRIGATION & LLNL-EP & LLNL-RTU & & \\
\hline JHR PLOT & LLNL-ER & LLNL-RY & & \\
\hline K RATE & LLNL-ES & RK TI/2 & & \\
\hline LLNL-BB & LLNL-ET & RR GRID & & \\
\hline LLNL-BE & LLNL-EU & $\mathrm{RR} \mathrm{T1/2}$ & & \\
\hline LOM PLOT & LLNL-EV & S-PIT & & \\
\hline LSKE & LLNL-EY & & & \\
\hline MICA PLOT & RUNIT DOME & & & \\
\hline \multicolumn{5}{|l|}{ MICROBE } \\
\hline \multicolumn{5}{|l|}{ MLS PLOT } \\
\hline \multicolumn{5}{|l|}{ MT WILLY } \\
\hline \multicolumn{5}{|l|}{ NA LEACHIN } \\
\hline \multicolumn{5}{|l|}{ NPK PLOT } \\
\hline \multicolumn{5}{|l|}{ SEA+K COMB } \\
\hline \multicolumn{5}{|l|}{ SI EFFECT } \\
\hline \multicolumn{5}{|l|}{ STEP PLOTS } \\
\hline \multicolumn{5}{|l|}{ SUPER K } \\
\hline \multirow{2}{*}{\multicolumn{5}{|c|}{$\begin{array}{l}\text { WELL B-1 } \\
\text { WELL B-4 }\end{array}$}} \\
\hline & & & & \\
\hline \multicolumn{5}{|l|}{ WR PLOT } \\
\hline XYZ PLOT & & & & \\
\hline
\end{tabular}


Appendix E: Number of Records Marshall Islands Database Series 
Table E-1. Marshall Islands Database Series.

Number of Records

\begin{tabular}{ccccccc}
\hline & \multicolumn{1}{c}{$\begin{array}{c}\text { Sample } \\
\text { Years }\end{array}$} & Vegetation & Soil & Canned & \multicolumn{2}{c}{ Radionuclide } \\
\cline { 5 - 7 } & Information & Processing & Processing & Sample & Gamma & Wet Chem \\
\hline 1973 & 4474 & NA & NA & NA & 61111 & NA \\
1974 & 0 & NA & NA & NA & NA & NA \\
1975 & 940 & NA & NA & NA & 6047 & 1232 \\
1976 & 0 & NA & NA & NA & NA & NA \\
1977 & 1726 & NA & NA & NA & 20793 & 712 \\
1978 & 5119 & NA & NA & NA & 45321 & 9774 \\
1979 & 1239 & NA & NA & NA & 15403 & 946 \\
1980 & 959 & NA & NA & NA & 11533 & 382 \\
1981 & 491 & NA & NA & NA & 5917 & 379 \\
1982 & 611 & NA & NA & NA & 8093 & 662 \\
1983 & 1492 & NA & NA & NA & 13469 & 930 \\
1984 & 975 & NA & NA & NA & 12353 & 91 \\
1985 & 3589 & NA & NA & NA & 34778 & 785 \\
1986 & 3214 & NA & NA & NA & 29722 & 370 \\
1987 & 3932 & 8325 & 491 & 3922 & 39827 & 51 \\
1988 & 4005 & 8967 & 659 & 4006 & 40346 & 0 \\
1989 & 4255 & 8127 & 1234 & 4253 & 42455 & 243 \\
1990 & 4075 & 7827 & 946 & 4078 & 37895 & 111 \\
1991 & 4742 & 10331 & 857 & 4743 & 26985 & 132 \\
1992 & 4044 & 7238 & 861 & 4045 & 4340 & 349 \\
1993 & 6022 & 7065 & 1523 & 6245 & 13654 & 0 \\
1994 & 5336 & 4825 & 272 & 1197 & 0 & 0 \\
\hline
\end{tabular}

NA=Not applicable

General Notes:

a Samples counted at the LLNL Gamma Analytical Facility and analyzed by the GAMANAL analysis program had 16 radioisotopes generated. The average $\%$ of radioisotopes at minimal detection activity (mda) for the years 1973 through 1994 (excluding 1991) is 71\%. Outside contracting laboratories did not report mda's.

b Sample information not imported into dBase for the year 1976.

c Duplicates included in number of records in sample information databases for 1979 through 1988.

d 1990 sample information database includes samples for others. These were not included in Table 1.

e Both Gamanal and GENIE systems were used during the year 1991. Mda's were not reported for samples analyzed by GENIE.

f The GENIE system was used in the analysis of the 1992 samples and mda's were not generated during this period.

g The GENIE system began reporting mda's for 1993 samples. Appendix E shows the list of radioisotopes reported. 
Appendix F: Radionuclide Isotope Designation Codes 
Table F-1. Radionuclide isotope designations used in the radionuclide databases.

Isotope Isotope Designation

$\begin{array}{ll}{ }^{40} \mathrm{~K} & 19040 \\ { }^{60} \mathrm{Co} & 28060 \\ { }^{90} \mathrm{Sr} & 38060 \\ { }^{134} \mathrm{Cs} & 55134 \\ { }^{137} \mathrm{Cs} & 55137 \\ { }^{152} \mathrm{Eu} & 63152 \\ { }^{155} \mathrm{Eu} & 63155 \\ { }^{210} \mathrm{~Pb} & 82210 \\ { }^{207} \mathrm{Bi} & 83207 \\ { }^{226} \mathrm{Ra} & 88226 \\ { }^{238} \mathrm{U} & 92238 \\ { }^{238} \mathrm{Pu} & 94238 \\ { }^{239} \mathrm{Pu} & 94239 \\ { }^{238}+240 \mathrm{Pu} & 94000 \\ { }^{241} \mathrm{Am} & 95241\end{array}$


Appendix G: Data Validation Procedures for Verifying Printouts 
There is a three page printout generated from the LLGAF with the following sample and analytical information:

Sample ID

Spectrum ID

Sample Date

Acquisition Date

Sample Type

Detector Name

Sample Quantity

Sample Geometry

Detector Geometry

Energy

Area

$\underline{\text { Nuclide }}$

Channel

Cts $/ \mathrm{Sec}$

\% Err

\% Abn

\% Eff

Uncorrected-pCi/gm

Corrected-pCi/gm
Sample Identification Number

Identification Number for the gamma spectrum generated

Reference date/Collection date of the sample

Start date for analysis of the sample

Sample description designation (Appendix D)

Name of detector sample was analyzed on

Weight of sample in grams

The type of container the sample was packaged in

Calibration designation showing sample geometry (container type) and sample composition

Gamma ray energy in $\mathrm{keV}$

Area under the peak in the spectrum in counts/second for a certain energy

Radionuclide Isotopes (Appendix E)

Channel Number to determine energy relationship

Counts per second in the peak area

Percent error showing statistical uncertainty

Percent abundance determined by the number of gamma rays per decay located in the radionuclide library

Percent efficiency determined by the observed counts/second versus the know gamma emission rate for a particular energy at calibration time

Concentration of gamma emitting radionuclides decay corrected to the acquisition date

Concentration of gamma emitting radionuclides decay corrected to collection date 
The following procedures below are to verify if a hard copy printout which includes sample and analytical information has met all the criteria before Final Validation.

\section{PAGE 1}

- Verify the date in the sample identification number with the sample date.

- Verify the detector geometry with the sample type in the sample identification number.

The following sample types should have the following detector geometry for a sample geometry of "F" referred to as a salmon can which is $4.0 \mathrm{~cm}$ in height, $8.0 \mathrm{~cm}$ in diameter with a volume of $201 \mathrm{~cm}^{3}$.

$\begin{array}{ll}\text { Sample type } & \text { Detector Geometry } \\ \text { PFD } & \text { F-FULL-COCONUT } \\ \text { PFA } & \text { F-FULL-COCONUT } \\ \text { PXX } & \text { F-FULL-POTATO } \\ \text { SPR } & \text { F-FULL-SOIL }\end{array}$

The following sample types should have the following detector geometry for a sample geometry of "P" referred to as a prindle vial which is $4.0 \mathrm{~cm}$ in height, $3.5 \mathrm{~cm}$ in diameter with a volume of $42 \mathrm{~cm}^{3}$.

Sample type Detector Geometry

PFD P-FULL-WATER

PFA P-FULL-WATER

PXX P-FULL-WATER

SPR P-FULL-SOIL 
The following sample types should have the following detector geometry for a sample geometry of " $\mathrm{T}$ " which is the designation for a $50 \mathrm{ml}$. centrifuge sample tube.

$\begin{array}{ll}\text { Sample type } & \text { Detector Geometry } \\ \text { PFE } & \text { T-3-GRAM-AMP } \\ \text { PFB } & \text { T-3-GRAM-AMP }\end{array}$

- Verify when sample geometry $=$ "F", sample quantity is $>50.0$ gms. From past experience it has been found that most samples in a F sample geometry are $>50.0$ gms. Go back to original sample log book to verify sample quantity if the above criteria is not met.

- Verify when sample geometry $=$ " $\mathrm{P}$ ", sample quantity is $<50.0$ gms. for vegetation and animal samples. Go back to original sample log book to verify sample quantity if the above criteria is not met.

- Verify the energies for the isotopes of ${ }^{137} \mathrm{Cs},{ }^{40} \mathrm{~K}$ and ${ }^{241} \mathrm{Am}$. For a vegetation sample check for ${ }^{137 \mathrm{Cs} \text { and }}{ }^{40 \mathrm{~K}}$. For soil samples, check for ${ }^{137 \mathrm{Cs} \text { and }}{ }^{241} \mathrm{Am}$. They should be the following:

$$
\begin{array}{ll}
{ }^{137 \mathrm{Cs}} & 662 \pm 1 \mathrm{keV} \\
{ }^{40 \mathrm{~K}} & 1461 \pm 1 \mathrm{keV} \\
{ }^{241} \mathrm{Am} & 59 \pm 1 \mathrm{keV}
\end{array}
$$

If an appropriate energy is missing, check for a Minimum Detection Activity (MDA) which is on page 3. If there is no MDA for the isotope in question, check for shifts in the energy peak and if peak shifts have occurred printout is to be recalculated.

- RECALCULATIONS will have to the performed due to errors in data entry and/or shifts in the peak spectrum as determined above. In this case the input values or the spectrum shift is corrected and the analysis program is run again using the same spectrum.

- Give printouts to be recalculated to the Data Managers for documentation before being returned to the LLGAF. 
- While verifying the energies described above, another problem could arise due to the electronics drifting from the detector's amplifier. The energies could split into two peaks. The following examples might be found:

$\begin{array}{ll}{ }^{137} \mathrm{Cs} & 662 \mathrm{keV} \\ & 663 \mathrm{keV} \\ & \\ 40 \mathrm{~K} & 1461 \mathrm{keV} \\ & 1462 \mathrm{keV} \\ & \\ & \\ & \\ & \\ & 59 \mathrm{Am} \\ & 60 \mathrm{keV}\end{array}$

- In this case the sample needs to be reanalyzed, resulting in a new spectrum and printout.

- Give printouts and physical sample to the Data Managers for documentation before being returned to the LLGAF.

\section{PAGE 2}

- The energies that were verified on page 1 should have radionuclide concentrations. Also, if the sample type is either PFE or PFB there should be a radionuclide concentration for the ${ }^{134} \mathrm{Cs}$ tracer.

- If radionuclide concentrations are missing give the printout to the Data Managers for documentation and further investigation into this problem.

\section{PAGE 3}

- All MDA's are reported on this page. If this page is missing the LLGAF can generate another.

- Give a list to the Data Managers for documentation to generate this particular page. 
Appendix H: Final Validation of Radionuclide Data Files 
Procedures for the Final Validation of Radionuclide Data Files against Printouts

After a sample is sent to the HEA LLGAF for gamma spectroscopy analysis a printout and an electronic radionuclide data text file is given to the data management group. It is the responsibility of this group to verify that the printout has been checked using the procedures in Appendix $\mathrm{F}$ and the electronic data file is identical to the printout. After all samples collected from a particular trip and atoll have been analyzed and a completed radionuclide data file is generated, final validation is ready to proceed. Below are the procedures utilized for final validation.

- Before a radionuclide data file can be verified against printouts, the recounts and recalculations need to be identified and corrected.

- If a printout is a recount or recalculation as determined in Appendix F.

1. The printout(recalculation) or sample(recount) will be given back to the LLGAF for new radionuclide data.

2. The sample ID and the problem will be documented in the event a question arises for that particular sample.

3. The electronic radionuclide data text file will be deleted by LLGAF personnel.

4. The printouts will be discarded by the LLGAF after a new printout is generated.

5. Do a follow-up and make sure you receive a new printout and the electronic radionuclide data is inserted into the data file.

- While the recounts and recalculation are being resolved, the validation process can continue.

- Check all radionuclide data and sample information in the data file against the printout to make sure it is identical. The radionuclide data and printouts are organized by collection date and sequence number. For each printout, if all the radionuclide and sample information is correct in the data file, the data are now verified. Initial and date the upper right corner of the first page of the printout.

Below are the problems that may be encountered and solutions for final validation.

- If two printouts are filed for validation.

Check all information on each printout and find the differences. Verify using the following directions to determine which one is correct.

1. If the counting date and/or spectrum identification are the only differences between the two printouts check with data mangers to determine if there was not a special request for two analyses. If this is the case, put a letter designation 
next to sample ID in the data file. If this was not the case, keep the most recent printout and radionuclide data.

2. If the sample geometries are different, choose the printout and radionuclide data where the geometry used coincides with the sample type in the sample ID.

3. If the sample quantity(weight) are different, go to the sample log book and verify which one is correct. Keep the printout and radionuclide data with the verified sample quantity

4. Check with the LLGAF to verify if their files and documentation agree with these decisions. Discard the old printouts and delete the associated radionuclide data

- If information was left out of the radionuclide data file, insert data from printout. If radionuclide data is not the same as in the printout and the reason can not be determined, have the sample recounted. Document this discrepancy.

- If no printout exist and the data file has radionuclide and sample information, document this discrepancy. A printout must be generated before data can be released.

- If radionuclide data is missing but a good printout was generated, document and request from the LLGAF an electronic data file for that sample.

- If an error is found from sample information generated from a dBase database do a follow-up to make sure that information is correct in all databases that pertains to that sample information.

- Before this data file can be imported into dBase, all corrections need to done and documented. Recounts and Recalculation take time to be resolved. Do a follow-up every week to make sure all problems were corrected and the new information has been validated. 